\title{
Working
}

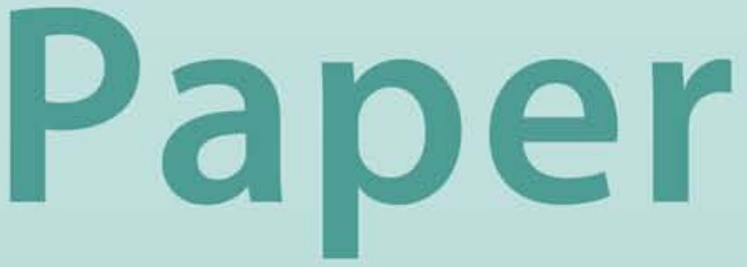




\title{
A Statistical Analysis of Banking Performance in the Eastern Caribbean Currency Union in the 1990 s
}

\author{
V. Hugo Juan-Ramón, Ruby Randall, and \\ Oral Williams
}




\title{
IMF Working Paper
}

IMF Institute and Western Hemisphere Department

\section{A Statistical Analysis of Banking Performance in the Eastern Caribbean Currency Union in the 1990s}

\author{
Prepared by V. Hugo Juan-Ramón, Ruby Randall, and Oral Williams ${ }^{1}$ \\ Authorized for distribution by Enzo Croce
}

August 2001

\begin{tabular}{l} 
Abstract \\
$\begin{array}{l}\text { The views expressed in this Working Paper are those of the author(s) and do not necessarily } \\
\text { represent those of the IMF or IMF policy. Working Papers describe rescarch in progress by the } \\
\text { author(s) and are published to elicit comments and to further debate. }\end{array}$ \\
\hline
\end{tabular}

Private foreign banks dominate the banking system although their market share declined in the 1990s while that of private indigenous banks increased. The banking system was not concentrated either within or across countries. Stigler's survivor test indicated that large banks tended to reduce their scale over time. Private foreign and private indigenous banks exhibited similar distributions with respect to operating expenses but private foreign banks were most profitable. High interest rate spreads appeared attributable to higher average costs related to market size and geographic peculiarities.

JEL Classification Numbers: C14, G21

Keywords: Bank Structure, Competition, Performance.

Author's E-Mail Addresses: vjuanramon@imf.org; rrandall@imf.org; and owilliams2@imf.org

\footnotetext{
${ }^{1} \mathrm{~V}$. Hugo Juan-Ramón is Deputy Division Chief at the IMF Institute, Ruby Randall is a Senior Economist at the IMF Human Resources Department, and Oral Williams is an Economist at the Western Hemisphere Department. We are grateful for many helpful comments received from Adolfo Barajas, Stanley Black, Enzo Croce, Michael DaCosta, Magda Kandil, Mohsin S. Khan, Saleh Nsouli, Evan Tanner and seminar participants at the University of San Andres (Argentina) and at the IMF Institute. We are also grateful to the ECCB for providing the data. Juan Carlos Flores provided excellent research assistance.
} 


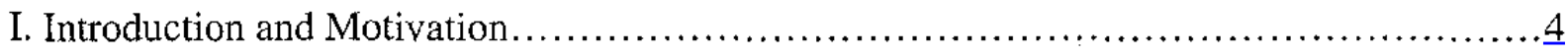

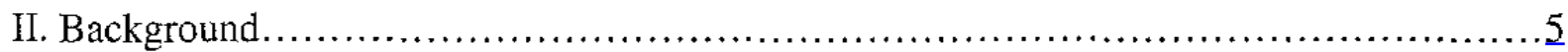

A. The Eastern Caribbean Monetary System ................................................... 5

B. The Eastern Caribbean Banking System .................................................... 5

C. Commercial Bank Performance Indicators..................................................... 8

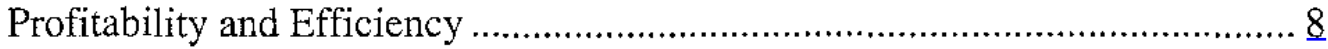

Financial Deepening.................................................................... 9

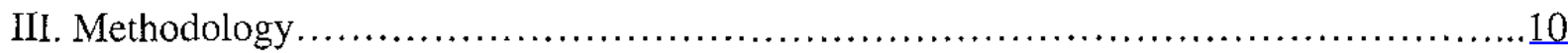

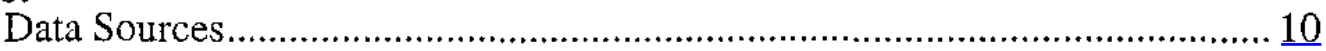

Analytical Techniques ............................................................. 10

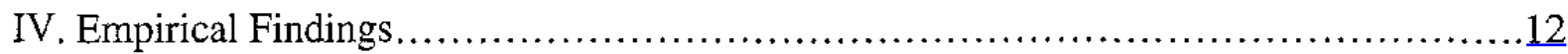

A. The Structure of Bank Ownership .............................................................. 12

B. Optimal scale in the ECCB area banking industry ....................................... 15

C. Bank Size and Concentration Within and Across Countries .............................. 19

D. Bank Concentration in the ECCB Area ...................................................... 23

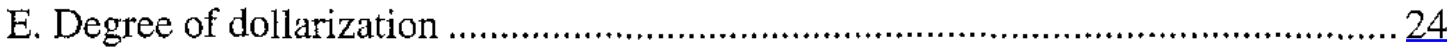

F. Is there evidence of a recent lending boom? ................................................. 25

G. Nonparametric Test: The Wilcoxon-Mann-Whitney Test ................................ 26

Bank's total asset as a percent of ECCB's area total asset (bank size)..........28

Operating expenses as a percent of total assets .......................................28

Net noninterest income as a percent of total assets..................................28

Net interest income as a percent of total assets ....................................... 29

Before-tax profit as a percent of total assets (bank profitability) ................. 29

Implicit lending rate (interest income as a percent of total loans) ................ 29

Implicit deposit rate (interest expense as a percent of total deposits) ............29

Implicit lending rate minus implicit deposit rate (spread) ......................... 30

Weighted average of explicit lending rates minus the implicit lending rate ... 30

Weighted average of explicit deposit rates minus the implicit deposit rate.... 31

V. Conclusion and Agenda for Future Research....................................

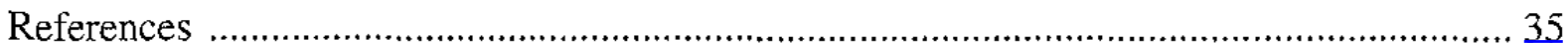

Figures

1. Scatter Diagram Between Bank Size and Before-tax Profit .............................. 17

2. Scatter Diagram Between Bank Size and Operating Expenses.............................. 18 
Tables

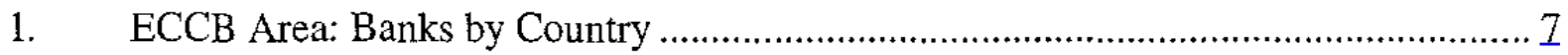

2. ECCB Area: Commercial Bank Profitability and Efficiency ................................. 9

3. Number of Banks in Each of the Ownership Groups ..................................... 12

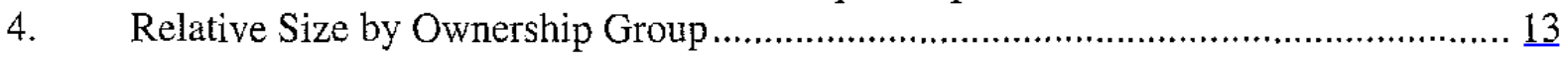

5. Foreign Bank Penetration During 1996-98 …............................................. 14

6. International Comparison of Foreign Bank Presence ........................................ 15

7. Percentage Distribution of Bank Sizes in the ECCB Area.................................... 16

8. Bank Size Within and Across Countries, and Country Size Across the ECCB

Area ............................................................................................ 20

9. Asset Concentration Indices by Period and Groups of Banks ............................ 23

10. Share of Deposits and Loans Denominated in U.S. Dollars During 1996-98 ........... 25

11. Total Loans as a Percentage of GDP for the System and by Groups .......................2 25

12. Summary of the Wilcoxon-Mann-Whitney Tests Assessing Bank Performance

Indicators Across Three Groups of Banks and Across the Subperiods of 1990-92, 1993-95, and 1995-98

Appendices

I. Caribbean Regions and Countries: Summary Indicators ................................... 37

II. Eastern Caribbean Area: Banks' Panel Identified by Country, Code, and

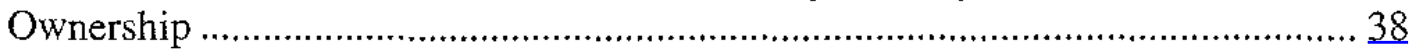

III. ECCB Institutional Requirements:

Credit Policy to Governments ............................................................ 39

Commercial Banks Legal Requirements ....................................................... 39

Commercial Banks Prudential Guidelines ................................................... 40 


\section{INTRODUCTION AND MOTIVATION}

The Eastern Caribbean Currency Union (ECCU) has a relatively long history of exchange rate stability based on a quasi-currency board arrangement with a fixed peg to the U.S. dollar since 1976. The monetary arrangements have served the region well in terms of price and economic stability. ${ }^{2}$ The region experienced real growth rates averaging 6 percent per annum during the 1980 's due in part to favorable terms of trade for primary commodities, concessional financing and inflows of foreign direct investment (FDI). ${ }^{3}$ Despite a slowing in real GDP growth to 3 percent per annum in the $1990 \mathrm{~s}$, due in part to a worsening in the terms of trade, declining preferential access to a number of markets and concessional finance, FDI inflows have been sustained, while per capita GDP averaged US $\$ 4,000$. Although, the economic performance of the ECCU was documented in van Beek et al. (2000), very little has been written on the central role and performance of commercial banks. Commercial banks are the primary intermediaries of savings and investment in the financial system with total assets of US\$3.5 billion at end-1999.

The Crown Agents Financial Advisory Service, (CAFAS, 1987), was the first study to examine the performance of commercial banks by addressing the prevalence of high interest rate spreads that were typical of the ECCU banking system. In particular, the authors concluded that foreign banks earn substantial profits due to wide interest rate spreads. Recent work by Randall (1998) suggests that the underlying reasons for persistently high interest rate spreads in the banking system were reserve costs, operational costs, and provision for loans losses. ${ }^{4}$ This study extends this earlier research by assessing the statistical significance of differences in bank performance indicators across three groups of banks in the ECCU (public, private indigenous and private foreign) across three sub-periods in the 1990's. In addition, the study investigates the optimal scale of banks, the structure of ownership, size and concentration of banks within and across countries and the extent of dollarization in the ECCU banking system. Further, the study determines whether the performance trends observable in the 1970's as documented in the CAFAS report, were still discernable in the 1990's.

The rest of the paper is organized as follows: Section I provides background information on the ECCU; Section III describes the data and methodology; Section IV discusses and summarizes the results; and Section V presents some concluding remarks and suggestions for further research.

\footnotetext{
${ }^{2}$ Inflation averaged 2.8 percent per annum during the 1990 s.

${ }^{3}$ Foreign direct investment flows averaged 10 percent of GDP during both the 1980's and 1990's.
}

${ }^{4}$ Implicit average interest rate spreads during 1991-96 were 2.2 percent for the U.S. compared to 7.9 percent for the ECCB area. 


\section{BACKgRound}

\section{A. The Eastern Caribbean Monetary System ${ }^{5}$}

The ECCU is comprised of eight countries that share a common regional central bank, the Eastern Caribbean Central Bank (ECCB) - six of which are independent member states and members of the IMF, and the remaining two (Anguilla and Montserrat) are dependent territories of the United Kingdom. This study focuses on banks in the independent member states-namely, Antigua and Barbuda, Dominica, Grenada, St. Kitts and Nevis, St. Lucia, and St. Vincent and the Grenadines-which are henceforth collectively referred to as the ECCB area. These countries range in size from St. Kitts and Nevis, with $269 \mathrm{sq} . \mathrm{km}$. to Dominica, with $750 \mathrm{sq}$. km., with populations ranging in size from 41,000 in St. Kitts and Nevis to 152,000 in St. Lucia, and with nominal GDP in 1998 ranging from US\$260 million in Dominica to US\$617 million in Antigua and Barbuda. In Appendix I, Table 13 presents some key indicators by regions and by countries in the Caribbean.

The ECCB was established in 1983. However, prior to this, the countries had shared a long tradition of monetary cooperation, with historical antecedents dating back to 1950 when the British Caribbean Currency Board (BCCB) was formed. The BCCB was replaced with the Eastern Caribbean Currency Authority (ECCA) in 1965 when the Eastern Caribbean dollar (EC\$) was introduced and initially pegged to the pound sterling at a rate of $\mathrm{EC} \$ 4.80=1$ British pound. Following a series of depreciations of the pound sterling, the parity was redefined with respect to the U.S. dollar in 1976 and pegged to the U.S. dollar at the then prevailing market cross-rate of EC $\$ 2.70$ to the U.S. dollar; the parity has since remained fixed at that level. The ECCA was replaced by the ECCB in July 1983 (see Appendix III for further details).

\section{B. The Eastern Caribbean Banking System}

The banking system of the ECCB area is comprised of 37 commercial banks, which are the most highly developed institutions in the financial sector (Table 1 shows "Banks by Country"). Of these 37 banks, there are 18 locally incorporated banks (called "indigenous" banks) and 19 foreign branch banks (owned by non-Caribbean nationals and Caribbean nationals from nonECCB member countries). Indigenous banks comprise private and public banks (where the government holds 50 percent or more of the total equity stake). Among the foreign branch banks, four multinational banks operate within the ECCB area banking system - Barclays Bank, the Bank of Nova Scotia, the Royal Bank of Canada and the Canadian Imperial Bank of Commerce-In the paper, we followed the ECCB which classifies banks as private foreign, private indigenous, and public banks (see Table 14, Appendix II).

${ }^{5}$ The discussion of ECCB institutional arrangements draws from the IMF Occasional Paper (No. 195, July, 2000) "The Eastern Caribbean Currency Union: Performance, Progress and Policy Issues” by F, van Beek, J. Rosales, M. Zermeño, R. Randall, and J. Shepherd. 
There were mergers and privatizations in the $1990 \mathrm{~s}$ in an attempt to improve the capitalization of some indigenous banks, and, during the review period, the number of public banks was reduced from six to four. The trend towards privatization has continued beyond the review period, with two additional privatizations taking place in $1999 .{ }^{6}$

During 1990-92, the first subperiod of the analysis, there were 5 public banks in the region: One public bank in Dominica, St. Kitts and Nevis, and St. Vincent and the Grenadines, and two banks in Grenada. During 1993-95, the second subperiod of analysis, there were also a total of 5 public banks; however, the distribution across the countries changed somewhat. In this period, following the privatization of the National Commercial Bank, the number of public banks in Grenada was reduced from two to one. During 1996-98, the final subperiod, there were 5 public banks in 1997, and 4 public banks thereafter as Grenada privatized its only remaining public bank. Thus, there were four public banks remaining after 1997, with one bank each in Dominica, St. Kitts and Nevis, St. Lucia, and St. Vincent and the Grenadines.

\footnotetext{
${ }^{6}$ The Caribbean Banking Corporation's (a subsidiary of Republic Bank of Trinidad and Tobago) acquisition of a 94 percent equity stake in Nevis Cooperative Bank, and the privatization of the National Commercial Bank, with the Government of St. Lucia retaining a 38 percent interest in the institution.
} 
Table 1. ECCB Area: Banks By Country

(As of December 31, 1999)

\begin{tabular}{|c|c|}
\hline COUNTRY/BANK & COUNTRY/BANK \\
\hline $\begin{array}{l}\text { ANTIGUA \& BARBUDA } \\
\text { Antigua \& Barbuda Investment Bank } \\
\text { Antigua Commercial Bank } \\
\text { Bank of Antigua } \\
\text { Bank of Nova Scotia } \\
\text { Barclays Bank } \\
\text { Caribbean Banking Corporation } \\
\text { CIBC Caribbean Ltd. } \\
\text { Royal Bank of Canada } \\
\text { Swiss American National Bank }\end{array}$ & $\begin{array}{l}\text { ST. KITTS \& NEVIS } \\
\text { Bank of Nevis } \\
\text { Bank of Nova Scotia } \\
\text { Barclays Bank } \\
\text { Nevis Co-operative Bank } \\
\text { St Kitts-Nevis-Anguilla National Bank } \\
\text { Royal Bank of Canada }\end{array}$ \\
\hline $\begin{array}{l}\text { DOMINICA } \\
\text { Bank of Nova Scotia } \\
\text { Banque Francaise Commercial } \\
\text { Barclays Bank } \\
\text { National Commercial Bank } \\
\text { Royal Bank of Canada }\end{array}$ & $\begin{array}{l}\text { ST. LUCIA } \\
\text { Bank of Nova Scotia } \\
\text { Barclays Bank } \\
\text { Caribbean Banking Corporation } \\
\text { CIBC Caribbean Ltd. } \\
\text { National Commercial Bank } \\
\text { Royal Bank of Canada } \\
\text { St Lucia Co-operative Bank }\end{array}$ \\
\hline $\begin{array}{l}\text { GRENADA } \\
\text { Bank of Nova Scotia } \\
\text { Barclays Bank } \\
\text { Grenada Bank of Commerce } \\
\text { Grenada Co-operative Bank } \\
\text { National Commercial Bank }\end{array}$ & $\begin{array}{l}\text { SI. VINCENT \& THE GRENADINES } \\
\text { Bank of Nova Scotia } \\
\text { Barclays Bank } \\
\text { Caribbean Banking Corporation } \\
\text { CIBC Caribbean Ltd. } \\
\text { National Commercial Bank }\end{array}$ \\
\hline
\end{tabular}

All of the four countries that still maintained public banks after 1997 have relatively large public banks, as measured by total assets. For example, although there was only one public bank in Dominica out of a total of five banks the share of public bank assets in the country's banking system was about 39 percent. St. Kitts and Nevis has one public bank out of a total of six banks; while the share of public bank assets in the country's banking system is about 40 percent. St. Vincent and the Grenadines has one public bank out of a total of five banks; while the share of public bank assets in the country's banking system is about 39 percent. St. Lucia has one public bank out of a total of seven banks; while the share of public bank assets in the country's banking system is about 22 percent. This is explained, in part, by the fact that public banks are the main repository for deposits of the social security schemes, which serve as the major source of funds for the public banks. 


\section{Commercial Bank Performance Indicators}

\section{Profitability and Efficiency}

Table 2 shows consolidated commercial bank profitability and efficiency indicators for the ECCB region as a whole for the three subperiods under review; namely, 1990-92, 1993-95, and 1996-98. The figures of average return on assets, defined as before-tax profit as a percent of total assets, rose from 2.3 percent during $1990-92$ to 2.6 percent during 1993-95, before declining again to 2.3 percent during 1996-98. These rates of return are similar to rates observed in other regions of the world. ${ }^{7}$

Interestingly, over time and particularly in the last subperiod, profits do not reflect the fact that net interest income (as a percentage of total assets) has increased from 4.4 percent in 1990-92 to 5.2 percent in 1996-98 and operating expenses (as a percentage of total assets) declined from 4.6 in 1990-92 to 4.3 in 1996-98. This could be attributed to an increase in the average ratio of loan loss provisions to total loans, which rose from 1.6 percent during 1990-92 to 2.7 percent during 1996-98. Although the ECCB's banking regulatory framework was strengthened and the provisioning requirement tightened in July 1995, the fact that the ratio continued to rise during the last subperiod could indicate a deterioration in the quality of banks' loan portfolios. In this connection, although time series data on the ratio of nonperforming loans to total assets are not available, van Beek, et al. (2000) present evidence that this ratio rose between 1997-99.

Table 2 also shows that the average implicit interest rate spread (calculated as interest income divided by average loans minus interest expenses divided average deposits) increased over the review period-rising from 7.7 percent during 1990-92 to 8.2 percent during 1996-98. Randall (1998) also reports a high (by U.S. standards) average implicit interest rate spread in the ECCB area during 1991-96: 7.9 percentage points, while the U.S. average was just 2.7 percent. However, a higher interest rate spread in the ECCB area did not translate into higher profitability, primarily because of relatively higher loan loss provisions and high operating costs, which stemmed from the fact that those countries are small with a geography that imposes higher costs. $^{8}$ In addition, many public banks (which are the repositories for the National Insurance Schemes) face additional legal restrictions, which limit their portfolio choices to the home market, and at times to investment in public institutions, and sometimes at below-market rates.

\footnotetext{
${ }^{7}$ Demirguc-Kunt and Huizinga (1998) report that elsewhere in Latin America in 1988-95 the return on assets was 2 percent in Argentina, 2.2 percent in Colombia, 3.5 percent in Costa Rica, 2.3 percent in the Dominican Republic, and 2.5 percent in Ecuador.

${ }^{8}$ Geography imposes costs due to establishment of branches in areas with low population density and procurement of technical services from abroad.
} 
Table 2. ECCB Area: Commercial Bank Profitability and Efficiency

\begin{tabular}{|c|c|c|c|}
\hline & $1990-92$ & 1993-95 & $1996-98$ \\
\hline \multicolumn{4}{|c|}{ Profitability Indicators } \\
\hline Net Interest Income (In percent of avg. total assets) & 4.4 & 5.1 & 5.2 \\
\hline Before-tax Profit (In percent of avg. total assets) & 2.3 & 2.6 & 2.3 \\
\hline Implicit Interest Rate Spread (In percent) & 7.7 & 8.5 & 8.2 \\
\hline \multicolumn{4}{|c|}{ Efficiency Indicators } \\
\hline Operating Expense (In percent of total avg. total assets) & 4.6 & 4.2 & 4.3 \\
\hline Of which: Personnel costs (In percent of avg. total assets) & 2.0 & 2.0 & 2.0 \\
\hline Provisions (In percent of total loans) & 1.6 & 1.9 & 2.7 \\
\hline
\end{tabular}

Source: Calculated from data provided by the ECCB.

\section{Financial Deepening}

To assess the depth and stability of the ECCB area banking sector, the following indicators were calculated: (i) deposits in the banking sector as a percentage of GDP-used as a measure of financial deepening (and monetization)-and the ratio of loans to deposits for the system-also used as measure of financial deepening; (ii) the coefficient of variation of the ratio of deposits to GDP for the period 1990-98, used as a measure of stability in the financial system; and (iii) the maturity structure of loans, also used as a measure of stability.

1. The degree of monetization was found to be high and increasing during the review period. The ratio of bank deposits in the ECCB area to GDP was 71 percent in 1990-92, 79 percent in 1993-95, and 91 percent in 1996-98. The same is true for the ratio of loans to deposits for the system, which was also relatively high and increased during the period. This ratio was 82 percent in 1990-92, 83 percent in 1993-95, and 88 percent in 1996-98.

Deposit-GDP ratios in excess of 50 percent are considered high by international standards; thus by comparison the depth of the ECCB area's financial system is relatively high. For instance, Rojas-Suarez and Weisbrod (1996) observed that in 1994, the ratio of deposits in the banking sector to GDP were in the range of 32 to 37 percent for Brazil, Chile, Colombia, Mexico and Venezuela, and about 15 percent for Argentina and Peru.

Moreover, not only did the extent of monetization in the ECCB area increase during the $1990 \mathrm{~s}$, but there is also evidence to support the view that the trend of increasing monetization has been ongoing in the region since the mid-1970s. The CAFAS Report 
(1987) shows that all countries in the ECCB area experienced an increase in their total bank deposits as a percentage of GDP from the mid-1970s to mid-1980s.

2. For 1990-98, the volatility in the ratio of deposits to GDP for the ECCB area, as measured by the coefficient of variation, was 11.4 percent. For the sake of comparison, for the period 1980-93, the volatility in the ratio of deposits to GDP, as measured by the coefficient of variation, was 274 percent for Argentina, 23 percent for Venezuela, 19 percent for Peru, 5 percent for Mexico, 3.4 percent for Colombia, and 2.5 percent for Chile.

3. The maturity structure of loans in the ECCB area changed significantly during the $1990 \mathrm{~s}$ towards more long-term loans. Total loans of maturity of 5 years or more as a percentage of total loans and overdrafts steadily increased from 38 percent in 1990 to 49 percent in 1997 (Table 42, SM/99/69).

\section{Methodology}

\section{Data Sources}

The primary source of data for the empirical analysis were the balance sheets and income statements of each bank in the ECCB area provided by the ECCB. Balance sheets were available for each semester for the period 1990-98, and income statements for each quarter of the review period. Each bank was then identified by a code, which conveys the following information: the country in which the bank operates and; whether it is private indigenous, private foreign, or public bank.

\section{Analytical Techniques}

Two analytical techniques were employed to examine some of the characteristics of the ECCB area's banking system namely: the Herfindahl Index and the Wilcoxon-Mann-Whitney nonparametric tests. The Herfindahl Index is used to examine the concentration in the banking industry and its evolution during the review period. This index is calculated for the Eastern Caribbean banking system as a whole; for public banks; for private indigenous banks; and for private foreign banks.

The Herfindahl index, $\mathrm{H}$, is defined as:

$$
H=100 * \sum_{i=1}^{N} a_{i}^{2}, \quad a_{i}=\frac{A_{i}}{\sum_{i=1}^{N} A_{i}},
$$

where: $A_{i}$ is the ith bank's attribute measuring its size (assets or deposits), and $\mathrm{N}$ is the number of banks during the period under consideration. 
The higher is $\mathrm{H}$, the greater the concentration of either assets or deposits in a few banks. It is straightforward to show that the lower limit of $\mathrm{H}$ (a totally even distribution of assets or deposits across banks) is $100 / \mathrm{N}$, and the upper limit of $\mathrm{H}$ (a totally uneven distribution) is 100 . The $\mathrm{H}$ index is calculated based on the distribution of assets by banks for the three subperiods considered and for various groups of banks (all banks, public, private indigenous and private foreign) and the results are reported below. In addition, the minimum bound of the $\mathrm{H}$ index $(100 / \mathrm{N})$ is reported for each group of bank and subperiod. Since the $\mathrm{H}$ index is affected by the number of banks, which varies across groups and subperiods, the ratio of the calculated value of $\mathrm{H}$ and the minimum bound for each bank group is also reported, so as to remove the influence of the number of banks and thereby facilitate comparisons across groups.

The Wilcoxon-Mann-Whitney nonparametric tests (also called the "Rank-Sum" test) is employed to assess the statistical significance, and hence robustness, of differences in bank performance indicators across the three groups of banks in the ECCB area, with a view to identifying changing trends over time. A range of performance indicators is employed for each bank, including size, measures of efficiency, implicit lending and deposit rates, spread, and a proxy for loan quality. The test provides a robust way to evaluate the hypothesis that two independent random samples originate from the same population.

The Wilcoxon-Mann-Whitney permits an assessment of the statistical significance of differences observed in only two groups of banks at any given point in time; therefore the data must be partitioned according to the nature of the hypothesis being tested. More specifically, suppose $\mathrm{X}_{1}$, $\mathrm{X}_{2}, \ldots, \mathrm{X}_{\mathrm{n}}$ is a random sample for any given indicator-say the share of each bank assets in total assets for a given region-of a continuous random variable $X$, and $Y_{1}, Y_{2}, \ldots, Y_{m}$ is an independent random sample of that same indicator but for a continuous random variable $Y$ where $\mathrm{X}$ and $\mathrm{Y}$ might represent private indigenous and private foreign banks, respectively. The nonparametric test evaluates the hypothesis that the distribution of the $\mathrm{X}$ values is the same as the distribution of $Y$ values-i.e., the null hypothesis is $\mathrm{H}_{0}: \mathrm{F}_{\mathrm{X}}(\mathrm{t})=\mathrm{F}_{\mathrm{Y}}(\mathrm{t})$ for all $\mathrm{t}$, versus the alternative, $\mathrm{H}_{\mathrm{A}}$, that $\mathrm{H}_{0}$ is false.

To carry out the test for any given indicator, averages are calculated for that indicator for each subperiod (1990-92, 1993-95, and 1996-98) for the entire panel of banks. Given the hypothesis that private indigenous banks (variable $X$ with " $n$ " observations) and private foreign banks (variable $\mathrm{Y}$ with " $\mathrm{m}$ " observations) are drawn from the same underlying bank population, all $\mathrm{m}+\mathrm{n}$ values are combined together, and the combined sample is ranked in order of magnitude (in descending order). The $\mathrm{X}$ values are then replaced by 1 's and the $\mathrm{Y}$ values are replaced by 0's, generating a sequence of $n$ 1's and $\mathrm{m} 0$ 's. The test formally assesses how intermixed are the 1 's and 0 's.

To implement the Wilcoxon-Mann-Whitney test, let $W_{Y}$ be the sum of the ranks of the $m \mathrm{Y}$ values. It can be shown that (see Chapter 10, of Harold J. Larson (1982)):

$$
E\left[W_{Y}\right]=\frac{m(m+n+1)}{2} \text { and } \operatorname{Var}\left[W_{Y}\right]=\frac{m n(m+n+1)}{12}
$$


The Wilcoxon-Mann-Whitney test can be formulated as:

Reject $\mathrm{H}_{0}: \mathrm{F}_{\mathrm{X}}(\mathrm{t})=\mathrm{F}_{\mathrm{Y}}(\mathrm{t})$ for all $\mathrm{t}$ if either $\mathrm{W}_{\mathrm{Y}} \leq \mathrm{t}_{0.025}$, or $\mathrm{W}_{\mathrm{Y}} \geq \mathrm{u}_{0.025}$

Where: $\mathrm{W}_{\mathrm{Y}}$ is the sum of the observed ranks of the $m \mathrm{Y}$ values, and

$$
t_{0.025}=E\left[W_{Y}\right]-1.96 \sqrt{\operatorname{Var}\left[W_{Y}\right]}-1 / 2 \text { and } u_{0.025}=E\left[W_{Y}\right]+1.96 \sqrt{\operatorname{Var}\left[W_{Y}\right]}+1 / 2
$$

\section{EMPIRICAL FINDINGS}

\section{A. The Structure of Bank Ownership}

A taxonomy of the banking structure during 1990-98 is presented in Tables 3 and 4, which show the relative importance of private foreign, private indigenous, and public banks in terms of percentage share (Table 3) and in terms of assets, deposits, and loans (Table 4). These tables show: the share of banks that are foreign-owned ("foreign penetration"), and the share of foreign banks' assets in total assets ("asset penetration"). The tables reveal that: (a) foreign bank penetration in the ECCB is relatively high when compared with the rest of the world, and (b) the degree of the foreign penetration is about the same as the degree of asset penetration.

Table 3. Number of Banks in Each of the Ownership Groups 1/

\begin{tabular}{|c|c|c|c|c|c|c|c|c|}
\hline \multirow{3}{*}{$\frac{\text { Periods }}{1990: \text { S1-92:S2 }}$} & \multirow{2}{*}{\multicolumn{2}{|c|}{ Total Banks }} & \multirow{2}{*}{\multicolumn{2}{|c|}{ Public Banks }} & \multicolumn{4}{|c|}{ Private Banks } \\
\hline & & & & & \multicolumn{2}{|c|}{ Indigenous Banks } & \multicolumn{2}{|c|}{ Foreign Banks } \\
\hline & 35 & (100) & 6 & (17) & 9 & (26) & 20 & $(57)$ \\
\hline $1993: S 1-95: S 2$ & 37 & $(100)$ & 5 & (13) & 11 & (30) & 21 & $(57)$ \\
\hline 1996:S1-98:S2 & 38 & $(100)$ & 52 & (13) & 12 & (32) & 21 & $(55)$ \\
\hline
\end{tabular}


Table 4. Relative Size by Ownership Group

\begin{tabular}{lcccc}
\hline & & & \multicolumn{2}{c}{ Private Banks } \\
\cline { 4 - 5 } Period/Attribute & Total & Public banks & Indigenous Banks & Foreign Banks \\
\hline & & & & \\
1990:S1-92:S2 & 100 & 28.1 & 16.7 & 55.2 \\
Assets & 100 & 27.5 & 16.0 & 56.5 \\
Deposits & 100 & 25.8 & 16.8 & 57.4 \\
Loans & & & & \\
& 100 & & & \\
1993:S1-95:S2 & 100 & 24.1 & 20.8 & 55.1 \\
Assets & 100 & 24.1 & 20.1 & 55.8 \\
Deposits & & 23.7 & & 56.1 \\
Loans & & & & \\
& 100 & 22.7 & 24.5 & 52.8 \\
1996:S1-98:S2 1/ & 100 & 23.1 & 24.0 & 52.9 \\
Assets & 100 & 22.6 & 23.4 & 54.0 \\
Deposits & & & & \\
Loans & & & & \\
\hline
\end{tabular}

1/ One public bank was privatized in 1996, thus thereafter the total number of banks were actually 37 , of which 4 were public banks.

From the viewpoint of the number of banks, the structure of the Eastern Caribbean banking system (public, private indigenous, and private foreign banks) has remained relatively stable in the last decade (Table 3). However, from the size viewpoint (measured either by assets, deposits or loans), foreign banks as a group have marginally decreased their importance in the system (as their share of assets declined from about 55 percent in the early 1990 s to about 53 percent in the late 1990s). ${ }^{9}$ On the other hand, indigenous private banks as a group have largely increased their importance in the system at the expense of the market share of public banks. In the last decade, indigenous private banks'assets as a percentage of the system's assets increased from about 17 percent to about 25 percent, while in the same period, the public banks' share of banking system assets declined from about 28 percent to about 23 percent. The same conclusion emerges when gauging the importance of each group by their share of either deposits or loans (Table 4).

These results are quite interesting when compared with the degree of foreign bank penetration during the 1980s. The CAFAS Report (1987) shows that in 1985, total assets and total deposits of foreign banks as a percentage of the system total assets and total deposits were 64 percent and 63 percent, respectively. At the time, that report argued that "the financial system is dominated

\footnotetext{
${ }^{9}$ This is a relatively high percentage compared with other countries. For example, Claessens, Dermiguc-Kunt and Huizinga (1998) report the average share of foreign bank assets in total bank assets for several countries during 1988-95, including: Argentina 10 percent, Australia 5 percent, Bolivia 36 percent, Brazil 30 percent, Canada 7 percent, Chile 25 percent, China 0 percent, Colombia 5 percent, Costa Rica 5 percent, Ecuador 52 percent, El Salvador 28 percent, Finland 0 percent, France 8 percent, Germany 25 percent, Hungary 61 percent, India 0 percent, Indonesia 16 percent, Israel 2 percent, Italy 1 percent, Jamaica 48 percent, Japan 21 percent, and Jordan 95 percent.
} 
by a small number of foreign commercial banks, despite the considerable success which the Governments and the ECCB have had in fostering local banking institutions." However, it is now apparent that foreign banks have decreased their importance since the mid-1980s, and that private indigenous banks, rather than the group of public banks, now have an enhanced presence and have helped to dilute the importance of foreign banks.

Nevertheless, foreign bank penetration is important in the ECCB area as a whole, since the foreign banks' share of the banking system's total assets was about 54 percent during 1996-98. Table 5 provides a breakdown of the foreign penetration and asset penetration share by country in the ECCB area, and the GDP share by country. Interestingly, differences in country foreign penetration rates were found to be highly correlated with national income (the coefficient of correlation is 0.81 ), which suggest that the differences in foreign penetration by country is primarily due to national income rather than national differences in, for example, laws governing foreign investments in the banking sector. The latter could be attributable to ongoing attempts to harmonize capital account restrictions and the investment climate in general within the ECCB monetary union.

Table 5. Foreign Bank Penetration During 1996-98

\begin{tabular}{lcccc}
\hline & $\begin{array}{l}\text { Number of } \\
\text { Foreign } \\
\text { Banks }\end{array}$ & $\begin{array}{l}\text { Foreign Banks as } \\
\text { Percent Total } \\
\text { Number of } \\
\text { Regional Banks }\end{array}$ & $\begin{array}{l}\text { Foreign Bank } \\
\text { Assets as Percent of } \\
\text { Regional Banking } \\
\text { System Total Assets }\end{array}$ & $\begin{array}{l}\text { Share in Total } \\
\text { Regional Average } \\
\text { GDP (1996-98) }\end{array}$ \\
\hline Antigua and Barbuda & 4 & & & \\
Dominica & 4 & 10.5 & 10.8 & 25.4 \\
Grenada & 3 & 10.5 & 6.2 & 10.8 \\
St Kitts and Nevis & 3 & 7.9 & 10.0 & 13.8 \\
St Lucia & 4 & 10.5 & 13.5 & 25.7 \\
St Vincent and the G. & 3 & 7.9 & 4.7 & 12.6 \\
Total & $\mathbf{2 1}$ & $\mathbf{5 5 . 2}$ & $\mathbf{5 3 . 8}$ & $\mathbf{1 0 0 . 0}$ \\
\hline
\end{tabular}

Table 6 reports the number of foreign banks as a percentage of total banks and foreign bank assets as a percentage of total assets for various regions of the world. This table shows that foreign bank penetration in the ECCB area is much higher than the percentage observed, on average, in the rest of Latin America (28 percent). 
Table 6. International Comparison of Foreign Bank Presence

\begin{tabular}{lcc}
\hline & Number of foreign banks & Foreign bank assets \\
\hline & (as a percentage of total) & (as a percentage of total) \\
& & \\
Regions & 31 & 27 \\
Africa & 28 & 30 \\
Asia & 25 & 28 \\
Latin America & 26 & 19 \\
Middle East and North Africa & 54 & 52 \\
Transitional Economics & 25 & 15 \\
Industrial Economies &
\end{tabular}

Source: Table 2 in Claessens, Dermiguc-Kunt, and Huizinga (1998).

Elsewhere within Latin America, Argentina was found to have a similar degree of foreign bank penetration as the ECCB area. Out of the 95 banks that existed in Argentina in September 1999, 39 banks (that is, 41 percent) were foreign; and those foreign banks hold about 53 percent of system assets. By contrast, Mexico was found to have a lower degree of foreign bank asset penetration than the ECCB area. Out of 37 banks that existed in Mexico in December 1999, 19 banks (that is, 51 percent) were foreign; however, those foreign banks held only about 20 percent of the system assets. ${ }^{10}$

\section{B. Optimal scale in the ECCB area banking industry}

We applied the Stigler's survivor principle to study the optimal scale of banks in the ECCB area. Stigler's hypothesis is that the continuous pressure upon firms' survival provides a source of information about the efficient scale of production of firms. Those firms having chosen inappropriately small or inappropriately large levels of "fixed" factors will have high average costs. In the long run, if they are to survive in the industry, such firms must shift to a more appropriate scale. And, as Stigler $(1958,1966)$ puts it "when the decline of some sizes of firms as a share of the industry is large enough or persistent enough to overcome the possibility that is due only to random shocks fluctuations, we may conclude that these size classes are comparatively inefficient."

Table 7 shows the percentage distributions of banks by size as a share of the industry for five subperiods from 1984 to 1998 . A bank size in a given subperiod is measured as a bank's average assets as a share of the industry (ECCB area banks) average assets. The data seem to support the

${ }^{10}$ Under the arrangements enacted after the 1994 crisis, a foreign controlled bank could represent up to 6 percent of total capital of the banking system (up from 1.5 percent under NAFTA) and foreign controlled banks, in the aggregate, could represent up to 25 percent of total capital (up from 8 percent under NAFTA). These constraints were further relaxed in 1999. 
applicability of the survivor principal since a cursory review of the table clearly reveals that there was a decline in the role of larger banks, which could be attributed to the fact that countries in the ECCB area are small, isolated from each other from a geographic viewpoint, and that economies of scale are limited by the extent of the market.

To further explore the issue of optimal scale, we plot a scatter diagram of bank size against before-tax profit as a percentage of total assets for the subperiods of 1990-92, 1993-95, and 1996-98 (Figure 1), and a scatter diagram of bank size against operating expenses as a percentage of total assets for the same subperiods (Figure 2). Those scatter diagrams reveal the following: (a) they visually show the fact established from reviewing Table 7: the decline in the relative number of larger banks; and (b) they suggest that larger size banks do not have any efficiency advantages (measured as either before-tax profits or operating expenses). In this connection, Birchwood (2000) found that in the CARICOM area, medium-sized banks had higher profitability, but that bank size does not matter in relation to operating unit costs.

Table 7. Percentage Distribution of Bank Sizes in the ECCB Area

Panel A: Private Foreign and Private Indigenous Banks

\begin{tabular}{|c|c|c|c|c|c|}
\hline Size Class & 1984-86 & $1987-89$ & $1990-92$ & 1993-95 & $1996-98$ \\
\hline & \multicolumn{5}{|c|}{ (In Percent) } \\
\hline $0.45-1.95$ & 41.7 & 37.0 & 44.8 & 37.5 & 42.4 \\
\hline $1.96-3.46$ & 16.7 & 40.7 & 34.5 & 46.9 & 39.4 \\
\hline $3.47-4.97$ & 20.8 & 11.1 & 10.3 & 6.3 & 15.2 \\
\hline $4.98-6.49$ & 20.8 & 11.2 & 10.4 & 9.3 & 3.0 \\
\hline Total & 100.0 & 100.0 & 100.0 & 100.0 & 100.0 \\
\hline
\end{tabular}

Panel B: All Banks, Including Public

\begin{tabular}{lrrrrr}
\hline \multicolumn{1}{c}{ Size Class } & $1984-86$ & $1987-89$ & $1990-92$ & $1993-95$ & $1996-98$ \\
\hline $0.45-1.95$ & 33.3 & 30.3 & 37.1 & 32.4 & 36.8 \\
$1.96-3.46$ & 20.0 & 36.4 & 37.1 & 43.2 & 36.8 \\
$3.47-4.97$ & 23.3 & 15.2 & 8.6 & 13.5 & 18.4 \\
$4.98-6.49$ & 23.4 & 18.1 & 17.2 & 10.9 & 8.0 \\
Total & $\mathbf{1 0 0 . 0}$ & $\mathbf{1 0 0 . 0}$ & $\mathbf{1 0 0 . 0}$ & $\mathbf{1 0 0 . 0}$ & $\mathbf{1 0 0 . 0}$ \\
\hline
\end{tabular}

Source: Calculated from data provided by the ECCB.

Note: Size is measured as bank average asset divided by ECCB area average assets. 
Figure 1. Scatter diagram between bank size and before-tax profit
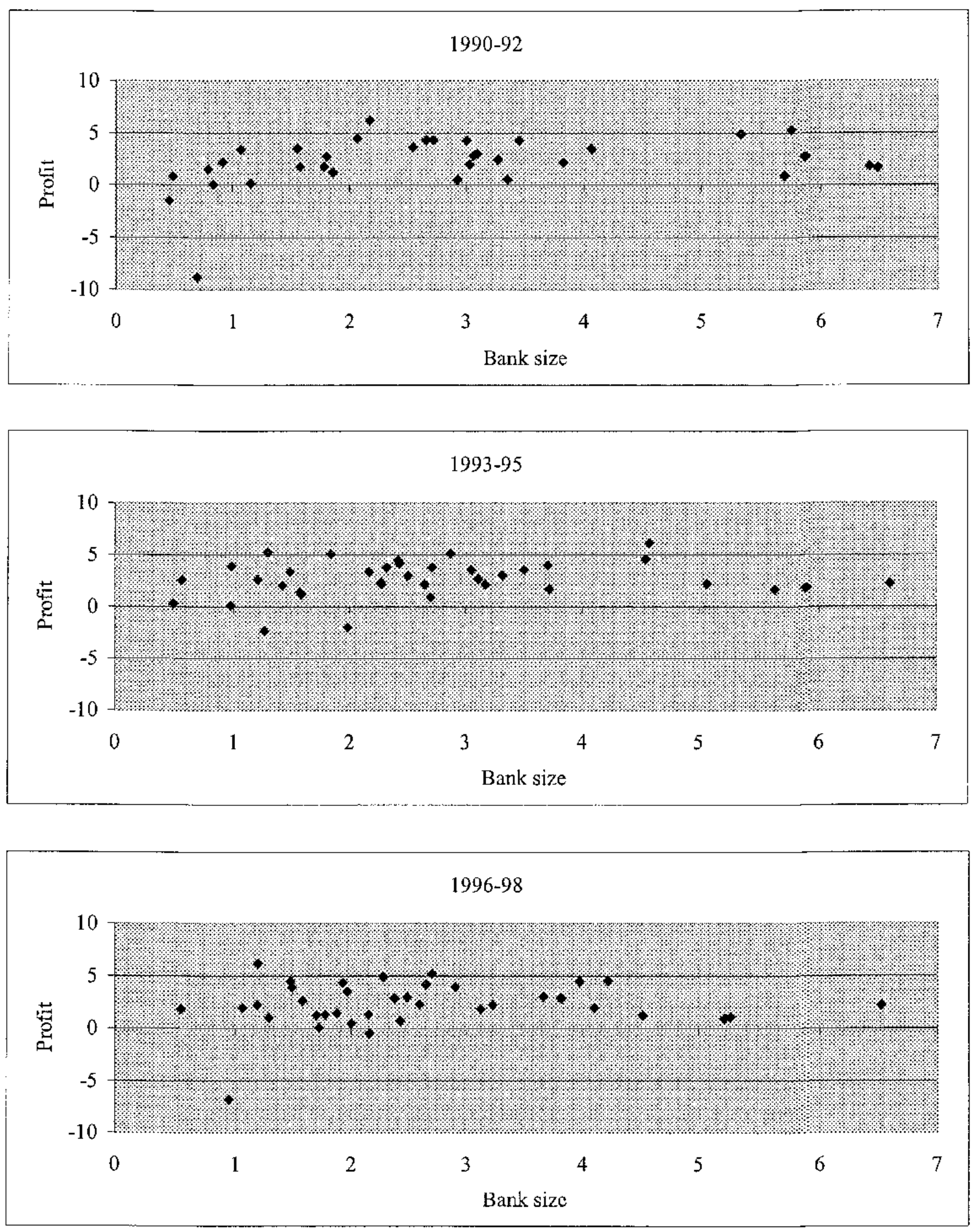
Figure 2. Scatter diagram between bank size and operating expenses
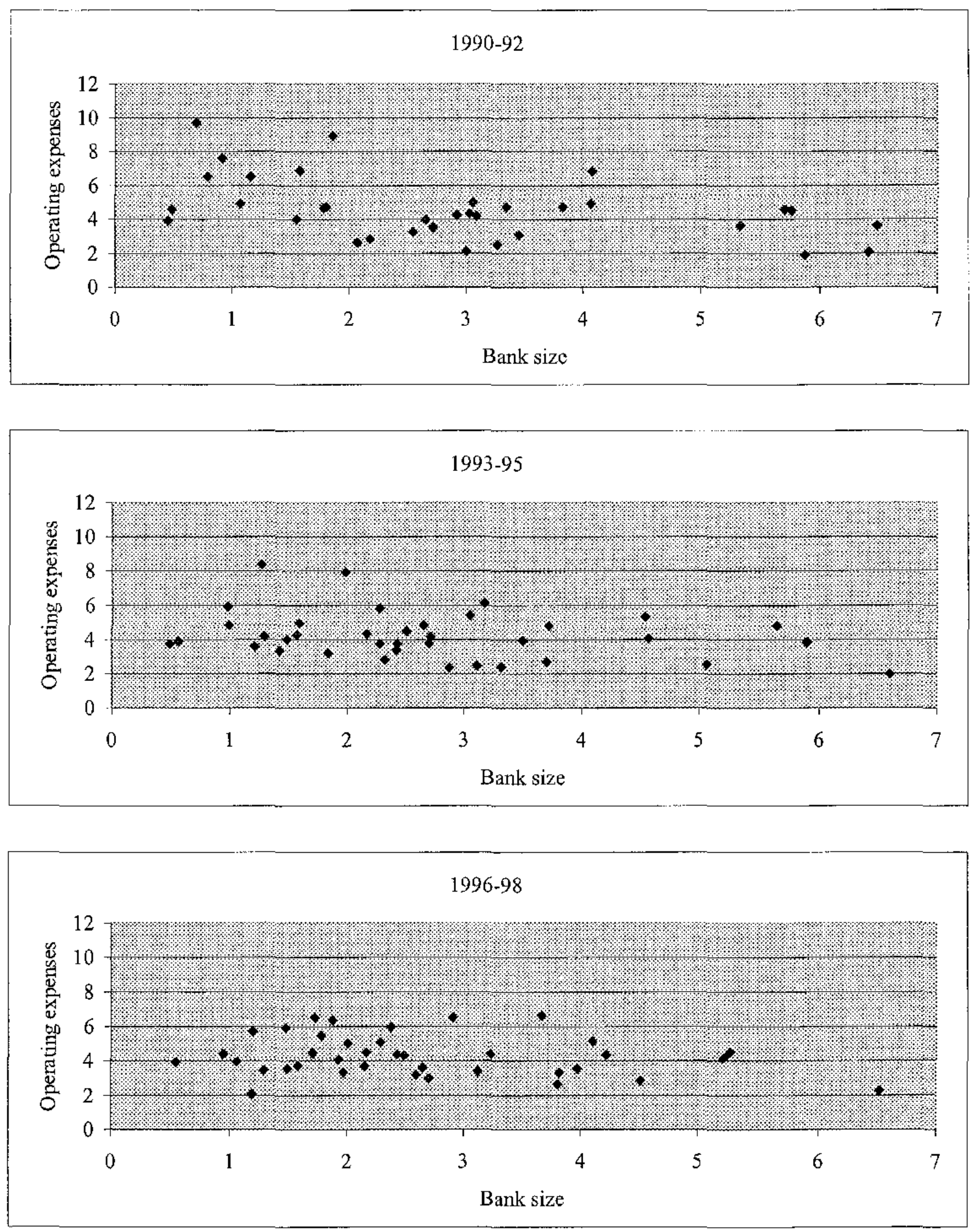


\section{Bank Size and Concentration Within and Across Countries}

The distribution of bank size (defined as a bank asset as a percentage of the ECCB system's total assets) within and across the six countries in the ECCB area from 1984 to 1990 is shown in Table 8 . From the table, the following conclusions emerged:

1. In general, banks were not concentrated either within or across countries. For example, regardless of the period under review (a) no one bank within a country accounted for more than 7 percent of the ECCB area banking system's total assets and (b) no one country accounted for more than 26 percent of the ECCB area banking system. St. Lucia and Antigua and Barbuda, the two largest economies within the ECCB area, accounted for no more than 50 percent of the ECCB area banking system assets.

2. No general dominance of foreign over indigenous banks based on size from an individual country perspective was observed.

3. For most countries, both the mean and the standard deviation of the size distribution either fell or remained constant over time. These results at a country level are consistent with results obtained in relation to the optimal scale of banks for the system as a whole: That relatively large banks tended to reduce their scale over time. 
Table 8. Bank Size Within and Across Countries, and Country Size Across the ECCB area 1/

\section{Period: 1984-86}

\begin{tabular}{|c|c|c|c|c|c|c|c|c|c|c|c|}
\hline \multirow{2}{*}{$\begin{array}{l}\text { Antiguand } \\
\text { Bank Cods }\end{array}$} & \multirow{2}{*}{ Barbuda } & \multicolumn{2}{|c|}{ St. Vincent and The } & \multicolumn{2}{|c|}{ Grenada } & \multicolumn{2}{|c|}{ St Ltela } & \multicolumn{2}{|c|}{$\mathrm{st} \mathrm{K} \mathrm{tts}$} & \multicolumn{2}{|c|}{ Dominca } \\
\hline & & Bank Code: & $\mathrm{Bank} \mathrm{S}_{12 \mathrm{Z}}$ & $\mathrm{Bank} \mathrm{Code}$ & Bank Size & Bank Code & Bank Size & Bank Code & Bank Size & Bank Code & Bank Sizc \\
\hline AGF-3 & 6.05 & VI-2-P & 5.56 & GF-1 & 5.09 & SLF-1 & 7.02 & $\mathrm{KI}-3-\mathrm{P}$ & 8.46 & DF-1 & 4.37 \\
\hline AGF-1 & 5.37 & $V F=1$ & 4.16 & GF-2-I-P & 4.14 & SLI-1-P & 4.10 & $\mathrm{KF}-1$ & 3.47 & DI-1-P & 2.57 \\
\hline$A G I-2$ & 5.23 & VI-1 & 1.79 & GI-1-1-P & 2.96 & SLF-3 & 3.94 & $\mathrm{KF}-6$ & 2.73 & DF-4 & 2.32 \\
\hline AGF-2 & 3.91 & VF-3 & 1.36 & GF-3 & 1.78 & SLF-4 & 3.16 & $\mathrm{KF}-5$ & 1.08 & DF-2 & 0.85 \\
\hline AGI-5 & 1.62 & $\mathrm{VF}-2$ & 0.96 & & & SLI-3 & 2.97 & KLI-4 & 0.51 & & \\
\hline AGI-1 & 0.85 & & & & & SLF-2 & 1.66 & & & & \\
\hline Country Size & 23.02 & & 13.82 & & 13.97 & & 22.84 & & 16.24 & & 10.10 \\
\hline Mean & 3.84 & & 2.76 & & 3.49 & & 3.81 & & 3.25 & & 2.53 \\
\hline Std. Dev. & 2.14 & & 2.00 & & 1.44 & & 1.80 & & 3.15 & & 1.44 \\
\hline
\end{tabular}

Period: $1987-89$

\begin{tabular}{|c|c|c|c|c|c|c|c|c|c|c|c|}
\hline Antunda & Bartuda & $\begin{array}{l}\text { St Ynce } \\
\text { Gren }\end{array}$ & $\begin{array}{l}\text { tand The } \\
\text { dines }\end{array}$ & G & & & & & & D & nea \\
\hline Bank Code & Bank Size & Bank Code & Bank Size & Bank Code & Bank $\mathrm{Stz}_{\mathrm{f}}$ & Bank Code & Bank Srze & Bank Code & Bank Size & Bank Cado & Bank Size \\
\hline AGI-2 & 6.08 & VI-2-P & 5.95 & GF-2-1-P & 3.88 & SLF-1 & 5.75 & $\mathrm{KI}-3-\mathrm{P}$ & 6.28 & DI-1-P & 3.56 \\
\hline AGF-3 & 4.91 & VF-1 & 3.30 & GF-1 & 3.87 & SLI-1-P & 5.47 & $\mathrm{KF}-1$ & 3.44 & DF-1 & 3.34 \\
\hline AGF-1 & 4.39 & VI-1 & 1.65 & GI-1-1-P & 3.32 & SLF-3 & 5.19 & $K F-6$ & 2.33 & DF.4 & 2.09 \\
\hline $\mathrm{AGF}-4$ & 3.34 & $\mathrm{VF}-3$ & 1.38 & GF-3 & 2.38 & SLI-3 & 2.84 & $\mathrm{KF}-5$ & 1.49 & DF-2 & 0.92 \\
\hline AGF-2 & 3.12 & VF-2 & 1.03 & & & SLF-4 & 2.50 & KLI-4 & 0.46 & DF -3 & 0.52 \\
\hline AGI-5 & 2.32 & & & & & SLF-2 & 1.89 & $\mathrm{KI}-2$ & 0.34 & & \\
\hline AGI-1 & 0.65 & & & & & & & & & & \\
\hline Country Size & 24.82 & & 13.31 & & 13.46 & & 23.64 & & 14.33 & & 10.44 \\
\hline Mean & 3.55 & & 2.66 & & 3.37 & & 3.94 & & 2.39 & & 2.09 \\
\hline Std. Dev. & 1.78 & & 2.03 & & 0.71 & & 1.71 & & 2.24 & & 1.37 \\
\hline
\end{tabular}


Table 8. (Continue) Bank Size Within and Across Countries, and Country Size Across the ECCB area 1/

Period: 1990-92

\begin{tabular}{|c|c|c|c|c|c|c|c|c|c|c|c|}
\hline \multicolumn{2}{|c|}{ Antgua and Barbuda } & \multicolumn{2}{|c|}{ St Vincentand The } & \multicolumn{2}{|c|}{ Gretada } & \multicolumn{2}{|c|}{ Stlucia } & \multicolumn{2}{|c|}{ st Kits } & \multicolumn{2}{|c|}{ Donurea } \\
\hline Bank Code & Bank Size & Bank Code & Bank Size & Bank Code & Bank Size & Bank Code & Bank Size & Bank Code & Bank Size & Bant Coge & Bank Size \\
\hline AGI-2 & 6.49 & VI-2-P & 5.87 & GF-1 & 3.83 & SLF-1 & 5.76 & $\mathrm{KI}-3-\mathrm{P}$ & 6.42 & DI-1-P & 3.45 \\
\hline AGF-3 & 4.07 & $V F-1$ & 3.07 & GF-2-1-P & 3.35 & SLI-1-P & 5.71 & $\mathrm{KF}-1$ & 3.03 & DF-1 & 3.10 \\
\hline AGF-1 & 4.07 & VI-1 & 1.81 & GI-1-1-P & 3.27 & SLF-3 & 5.33 & $\mathrm{KF}-6$ & 2.08 & $\mathrm{DF}-4$ & 2.18 \\
\hline $\mathrm{AGF}-4$ & 3.01 & VF-3 & 1.56 & GF-3 & 1.79 & SLI-3 & 2.93 & $\mathrm{KF}-5$ & 1.58 & DF-2 & 1.08 \\
\hline $\mathrm{AGF}-2$ & 2.72 & VF-2 & 0.92 & & & SLF-4 & 2.66 & $\mathrm{KI}-2$ & 0.49 & DF-3 & 0.80 \\
\hline AGI-5 & 1.86 & & & & & SLF-2 & 2.55 & KLI-4 & 0.46 & & \\
\hline AGI-4 & 1.16 & & & & & & & & & & \\
\hline AGI-3 & 0.84 & & & & & & & & & & \\
\hline AGI-1 & 0.70 & & & & & & & & & & \\
\hline Country Size & 24.92 & & 13.23 & & 12.25 & & 24.94 & & 14.06 & & 10.60 \\
\hline Mean & 2.77 & & 2.65 & & 3.06 & & 4.16 & & 2.34 & & 2.12 \\
\hline Std. Dev. & 1.90 & & 1.97 & & 0.88 & & 1.59 & & 2.22 & & 1.18 \\
\hline \multicolumn{12}{|c|}{ Period: 1993-95 } \\
\hline Antigua a & Barbuda & \multicolumn{2}{|c|}{$\begin{array}{l}\text { St Uncent and Tlic } \\
\text { Grenadines }\end{array}$} & & & \multicolumn{2}{|c|}{ st tura } & \multicolumn{4}{|c|}{ Dommica } \\
\hline Bank code & Bank size & Bank Code & Bank Size & Bank Code & Bank Size & Bank Code & Bank size & Bank Code & Bank Size & Bank Cade & Bank Sire \\
\hline AGI-2 & 5.90 & VI-2-P & 5.07 & GF-2-2 & 3.72 & SLI-1-P & 5.65 & $\mathrm{KI}-3-\mathrm{P}$ & 6.61 & DI-1-P & 3.71 \\
\hline AGF-1 & 3.17 & VI-1 & 2.28 & GF-1 & 3.50 & SLF-3 & 4.58 & KF-5 & 3.32 & DF-1 & 2.51 \\
\hline AGF-3 & 3.05 & VF-1 & 2.28 & GI-1-1-P & 3.11 & SLF-1 & 4.55 & $\mathrm{KF}-1$ & 2.65 & DF-4 & 1.84 \\
\hline AGF-4 & 2.87 & $\mathrm{VF}-3$ & 1.49 & GF-3 & 2.17 & SLF-4 & 2.71 & KF-6 & 2.32 & DF-3 & 1.30 \\
\hline AGF-2 & 2.43 & VF-2 & 0.99 & GI-2 & 1.42 & SLI-3 & 2.70 & $\mathrm{KI}-2$ & 0.57 & $\mathrm{DF}-2$ & 1.21 \\
\hline AGI-5 & 1.99 & & & & & SLF-2 & 2.42 & KLI-4 & 0.49 & & \\
\hline AGI-4 & 1.59 & & & & & SLI-2 & 1.57 & & & & \\
\hline AGI-1 & 1.27 & & & & & & & & & & \\
\hline AGI-3 & 0.98 & & & & & & & & & & \\
\hline Country Size & 23.26 & & 12.10 & & 13.93 & & 24.18 & & 15.96 & & 10.57 \\
\hline Mean & 2.58 & & 2.42 & & 2.79 & & 3.45 & & 2.66 & & 2.11 \\
\hline Std. Dev. & 1.47 & & 1.58 & & 0.96 & & 1.47 & & 2.24 & & 1.03 \\
\hline
\end{tabular}


Table 8. (Continuc) Bank Size Within and Across Countries, and Country Size Across the ECCB area 1/

Period: 1996-98

\begin{tabular}{|c|c|c|c|c|c|c|c|c|c|c|c|}
\hline \multirow{2}{*}{\multicolumn{2}{|c|}{$\begin{array}{l}\text { Antigus and Barbuda } \\
\text { Bank Code }{ }_{\text {Bank Size }}\end{array}$}} & \multicolumn{2}{|c|}{$\begin{array}{l}\text { St. Yricent and The } \\
\text { Grenadines }\end{array}$} & \multicolumn{2}{|c|}{ Grenada } & \multicolumn{2}{|c|}{ st tucia } & \multicolumn{2}{|c|}{ St Ktts: } & \multicolumn{2}{|c|}{ Domimca } \\
\hline & & Bank Code & Bank Size & Bank Code & Bank Size & Bank Cole & Bank Size & Bank Code & Bank Size & Bank Gode & Bank size \\
\hline AGI-2 & 5.22 & $\mathrm{VI}-2-\mathrm{P}$ & 4.52 & GF-2-2 & 4.10 & SLI-1-P & 5.27 & $\mathrm{KI}-3-\mathrm{P}$ & 6.52 & DI-1-P & 3.81 \\
\hline AGF-3 & 3.98 & VI-1 & 2.43 & GF-1 & 3.23 & SLF-3 & 4.22 & $\mathrm{KF}-5$ & 3.82 & DF-1 & 2.01 \\
\hline AGF-1 & 2.91 & VF-1 & 1.78 & GI-1-2 & 3.13 & SLF-1 & 3.66 & KF-1 & 2.38 & $\mathrm{DF}-4$ & 1.49 \\
\hline $\mathrm{AGF}-4$ & 2.70 & VF-3 & 1.58 & GI-1-1-P & 2.59 & SLF-2 & 2.65 & KF-6 & 1.97 & DF-3 & 1.48 \\
\hline AGF-2 & 1.93 & $\mathrm{VF}-2$ & 1.20 & GF-3 & 2.28 & SLF-4 & 2.49 & $\mathrm{KI}-2$ & 1.19 & $\mathrm{DF}-2$ & 0.94 \\
\hline AGI-1 & 1.88 & & & GI-2 & 1.29 & SLI-3 & 2.16 & KLI-4 & 0.55 & & \\
\hline AGI-5 & 1.72 & & & & & SLI-2 & 2.15 & & & & \\
\hline AGI-4 & 1.70 & & & & & & & & & & \\
\hline AGI-3 & 1.06 & & & & & & & & & & \\
\hline Country Size & 23.11 & & 11.51 & & 16.63 & & 22.61 & & 16.43 & & 9.73 \\
\hline Mean & 2.57 & & 2.30 & & 2.77 & & 3.23 & & 2.74 & & 1.95 \\
\hline Std. Dev. & 1.31 & & 1.32 & & 0.96 & & 1.19 & & 2.16 & & 1.11 \\
\hline
\end{tabular}

${ }^{1}$ Bank size is defined as bank's assets as a percentage of ECCB total assets 


\section{Bank Concentration in the ECCB Area}

To gauge the degree of concentration in the ECCB area banking industry, we calculated the Herfindahl index for all banks in the ECCB area, as well as for public, private indigenous, and private foreign banks as a group. In each case, the index was calculated for the three subperiods under review. The results of this exercise are presented in Table 9 below.

Table 9. Asset Concentration Indices by Period and Groups of Banks

\begin{tabular}{lrrr}
\hline \multicolumn{1}{c}{ Indices } & 1990-92 & 1993-95 & 1996-98 \\
\hline All banks & & & \\
$\mathrm{H}$ & 4.0 & 3.5 & 3.4 \\
100/N & 2.9 & 2.7 & 2.6 \\
$\mathrm{H}^{*} \mathrm{~N} / 100$ & 1.4 & 1.3 & 1.3 \\
& & & \\
Public banks & & & \\
$\mathrm{H}$ & 18.0 & 21.4 & 21.7 \\
100/N & 16.7 & 20.0 & 20.0 \\
$\mathrm{H}^{*} \mathrm{~N} / 100$ & 1.1 & 1.1 & 1.1 \\
Indigenous private banks & & & \\
$\mathrm{H}$ & & & 13.5 \\
$100 / \mathrm{N}$ & 21.6 & 15.7 & 8.3 \\
$\mathrm{H}^{*} \mathrm{~N} / 100$ & 11.1 & 9.1 & 1.6 \\
& 1.9 & 1.7 & \\
Foreign private banks & & & 5.5 \\
$\mathrm{H}$ & & & 4.8 \\
$100 / \mathrm{N}$ & 6.2 & 5.4 & 1.2 \\
H*N/100 & 5.0 & 4.8 &
\end{tabular}

Table 9 reveals the following: (a) from the viewpoint of a bank's total assets, the low $\mathrm{H}$ indices indicate that banking activity in the ECCB area does not appear to be heavily concentrated in a small number of banks (basically the same results are obtained when one measures concentration from the viewpoint of deposits rather than assets); (b) the group of indigenous private banks tended to become less concentrated over time; (c) the groups of foreign and public banks have maintained about the same degree of concentration over time; (d) Since mid-1980s, the group of all banks has become less concentrated (in 1984-86, the $\mathrm{H}$ index for this group was 4.5 percent).

For the sake of comparison, the concentration index was also calculated for Argentina and Mexico, For Argentina, the $\mathrm{H}$ index for assets of all banks was about 5.4 percent during June-September 1999. This is about the same as the level currently observed in the ECCB area. However, after controlling for the number of banks, Argentina's index $\left(\mathrm{H}^{*} \mathrm{~N} / 100\right)$ was about 5 times larger than that of the ECCB area. For Mexico, the concentration index for assets of all banks were about 12 percent during June-September 1999, reflecting the fact that the three largest banks held about 53 percent of the banking system's total assets. Thus, Mexico had a much larger bank concentration than the ECCB area. 
Public banks became relatively more concentrated over time as their share of banking system assets increased. This trend reflected the increase in deposits associated with the National Insurance Schemes whose growth in contributions is attributable to demographic factors. Indigenous private banks tended to become less concentrated over time with increased competition within this group and because of a smaller share of banking system assets relative to public banks and longer established foreign private banks.

\section{E. Degree of dollarization}

The degree of dollarization in the ECCB area banking system is low, thus indicating that there is credibility in the currency union and confidence in the exchange rate parity. There was however, a small increase in dollarization during the 1990s. For the system as a whole and for the three subperiods we study, the share of deposits denominated in U.S. dollars in total deposits was 3.5 percent, 4.0 percent, 5.6 percent, respectively; and the share of loans denominated in U.S. dollar in total loans for the same subperiods was 3.3 percent, 4.1 percent, 4.4 percent, respectively.

For the sake of comparison: In Argentina, the share of deposits denominated in U.S. dollars in total deposits, increased from about 42 percent in the 1992 to about 65 percent in 1999; in Peru, the same indicator, has fluctuated around 65 percent during the $1990 \mathrm{~s}$; in Uruguay, the same indicator, hovered around 89 percent during the 1990s. Argentina, Peru, and Uruguay started dollarization in response to the high inflation they experienced in the $1970 \mathrm{~s}$ and 1980s. However, dollarization remained high in those countries in spite of having implemented adjustments in the 1990s and reduced inflation for several years. In Chile, on the other hand, the share of deposits denominated in U.S. dollars in total deposits, fell from about 17 percent in 1990-91 to 10 percent in 1999. In all of these countries, their share of loans denominated in U.S. dollars in total loans, are similar to their share of deposits denominated in U.S. dollars in total deposits.

We also studied the degree of dollarization (measured by deposits and loans in U.S. dollars) by ownership group. The results are presented in Table 10, and the following conclusions emerged: (a) in the subperiod 1996-98, most banks were receiving deposits denominated in U.S. dollars, however, most banks had a share of less than 10 percent; (b) in the subperiod 1996-98, the number of banks making loans in U.S. dollars was smaller than the number of banks receiving U.S. dollar denominated deposits; (c) most banks making loans in U.S. dollars had a U.S. dollar loan portfolio of 10 percent or less; (d) the banks operating in U.S. dollars were intermixed among private foreign, private indigenous, and public banks. Thus operating in U.S. dollars is not a peculiarity of foreign banks. 
Table 10. Share of Deposits and Loans Denominated in U.S. Dollars during 1996-98

\begin{tabular}{lrrr}
\hline & \multicolumn{3}{c}{ Percent } \\
\cline { 2 - 4 } & $0.5-10.0$ & $10.1-30.0$ & $30.1-50$ \\
\hline U.S. dollar deposits in total deposits & & & \\
Number of banks & 26 & 6 & 2 \\
Of which: foreign & 17 & 0 & 1 \\
Of which: public & 5 & & \\
U.S. dollar loans in total loans & & 4 & 1 \\
& & 3 & 1 \\
Number of banks & 13 & 0 & 0 \\
Of which: foreign & 8 & 1 & \\
Of which: public & & & \\
\end{tabular}

\section{F. Is there evidence of a recent lending boom?}

Given that lending booms can foster financial vulnerability by contributing to an eventual decline in the quality of banks' assets, and that most financial crises were preceded by a period of rapid growth in banking system credit as a percentage of GDP, we report in Table 11 the ratio of total loans to GDP in the ECCB area banking system and in each of the ownership groups for the three subperiods considered.

Table 11. Total Loans as a Percentage of GDP for the System and by Groups

\begin{tabular}{|c|c|c|c|c|}
\hline & ECCB System & Public Banks & $\begin{array}{c}\text { Private } \\
\text { Indigenous Banks }\end{array}$ & $\begin{array}{c}\text { Private Foreign } \\
\text { Banks }\end{array}$ \\
\hline 1990:S1-92:S2 & 58.1 & 15.0 & 9.8 & 33.3 \\
\hline $1993: \mathrm{S} 1-95: \mathrm{S} 2$ & 65.7 & 15.5 & 13.2 & 36.9 \\
\hline 1996:S1-98:S2 & 80.0 & 18.1 & 18.7 & 43.2 \\
\hline
\end{tabular}

Table 11 shows no evidence of a rapid credit expansion in the ECCB area during the review period, as loans as a percentage of GDP grew by only 22 percentage points between 1990-92 and 1996-98. This is a rather small increase compared with the rapid expansion (and in a shorter period) experienced by several countries prior to the onset of the crisis. For example, Gavin and Hausmann (1996) ${ }^{11}$ report that for Mexico this measure jumped from 10 percent

${ }^{11}$ Although the examples refer to credit to the private sector as a percentage of GDP, the analysis remains comparable given that loans extended to the government by the ECCB 
in 1990 to nearly 40 percent in 1994 . The authors report similar pattern of rapid growth in banking system credit as a percentage of GDP for Argentina (1981), Chile (1981-82), Colombia (1982-83), Uruguay (1982), Norway (1987), Finland (1991-92), Japan (1992), and Sweden (1991).

For the three subperiods and for each of the six countries in the ECCB area, we calculated total loan (by all banks) for each country as a percentage of the country's GDP. Based on this indicator, there is no evidence of a rapid credit expansion at a country level either. In none of the six countries, did loans as a percentage of GDP grow by more than 25 percentage points between 1990-92 and 1996-98.

\section{G. Nonparametric Test: The Wilcoxon-Mann-Whitney Test}

The Wilcoxon-Mann-Whitney test was applied to the following bank performance indicators to test for the presence of statistical significant difference across bank groups: (a) bank size, defined as the ratio of a given bank's total assets to the ECCB's banking system total assets; (b) operating expenses as percent of total assets, defined as personnel costs plus other noninterest expenses, excluding provisions, as a percent of total assets; (c) net non-interest income as a percent of total assets, defined as non-interest income as a percent of total assets minus non-interest expenses as a percent of total assets; (d) net interest income as a percent of total assets, defined as interest income as a percent of total assets minus interest expenses as a percent of total assets; (e) profit as a percent of total assets, defined as before-tax profits as a percent of total assets; (f) implicit lending rate, defined as interest income as a percent of total loans; ( $\mathrm{g}$ ) implicit deposit rate, defined as interest expense as a percent of total deposits; (h) spread, defined as the implicit lending rate minus the implicit deposit rate; (i) weighted average of explicit (quoted) lending rates minus the implicit lending rate; and (j) weighted average of explicit (quoted) deposit rates minus the implicit deposit rate.

In general, the two groups of banks tested were: Private foreign versus private indigenous banks, excluding the public banks; and public banks versus the rest of banks (private indigenous and private foreign banks). The application of the Wilcoxon-Mann-Whitney Test yielded the results described below and summarized in Table 12.

banking system is quite small: 10 percent of the commercial banks loan portfolio. Therefore, total loans is a suitable proxy for credit to the private sector in the ECCB area. 
Table 12. Summary of the Wilcoxon-Mann-Whitney Tests Assessing Bank Performance Indicators Across

Three Groups of Banks and Across the Subperiods of 1990-92, 1993-95, and 1996-98 1

\begin{tabular}{|c|c|c|c|c|c|c|c|c|c|}
\hline $\operatorname{Size}^{2}$ & $\begin{array}{c}\text { Operating } \\
\text { expenses as } \% \\
\text { of total assets } 3\end{array}$ & $\begin{array}{l}\text { Net non- } \\
\text { interest income } \\
\text { as \% of total } \\
\text { assets }\end{array}$ & $\begin{array}{c}\text { Net interest } \\
\text { income as \% of } \\
\text { total assets } \underline{5}\end{array}$ & $\begin{array}{l}\text { Profit as } \% \text { of } \\
\text { total assets }\end{array}$ & $\begin{array}{c}\text { Implicit } i_{L} \\
\text { (interest } \\
\text { income as } \% \text { of } \\
\text { total loans) }^{2}\end{array}$ & $\begin{array}{c}\text { Implicit } i_{D} \\
\text { (interest } \\
\text { expense as \% } \\
\text { of total } \\
\text { deposits) }\end{array}$ & $\begin{array}{c}\text { Spread } \equiv \\
\text { implicit } i_{L} \\
\text { minus implicit } \\
i_{D} 9\end{array}$ & $\begin{array}{c}\mathrm{D} \equiv \text { Average } \\
\text { quoted } i_{L} \text { minus } \\
\text { implicit } i_{L} \underline{10}\end{array}$ & $\begin{array}{c}\mathrm{D} \equiv \text { Average } \\
\text { quoted } i_{D} \\
\text { minus implicit } \\
i_{D} \underline{11}\end{array}$ \\
\hline $\begin{array}{c}F \sim I \\
276 \in[265,355]\end{array}$ & $\begin{array}{c}F \sim I \\
297 \in[258,342]\end{array}$ & $\begin{array}{c}F>1 \\
243 \notin[258,342]\end{array}$ & $\begin{array}{c}F>I \\
232 \notin[258,342]\end{array}$ & $\begin{array}{c}F>I \\
217 \notin[258,342]\end{array}$ & $\begin{array}{c}F-I \\
273 \in[258,342]\end{array}$ & $\begin{array}{c}\mathrm{F} \sim \mathrm{I} \\
336 \in[258,342]\end{array}$ & $\begin{array}{c}F>I \\
235 \notin[258,342]\end{array}$ & $\begin{array}{c}F \sim 1 \\
250 \in[201,267]\end{array}$ & $\begin{array}{c}F \sim I \\
222 \in[201,267]\end{array}$ \\
\hline $\begin{array}{c}\mathrm{P}>\mathrm{R} \\
38 \notin[48,132]\end{array}$ & $\begin{array}{c}P<R \\
139 \notin[47,128]\end{array}$ & $\begin{array}{c}P-I \\
23 \in[22,53]\end{array}$ & $\begin{array}{c}\mathrm{P} \sim \mathrm{I} \\
38 \in[22,53]\end{array}$ & $\begin{array}{c}P \sim I \\
22 \in[22,53]\end{array}$ & $\begin{array}{c}\mathrm{P}<\mathrm{R} \\
144 \notin[47,128]\end{array}$ & $\begin{array}{c}\text { P }-\mathrm{R} \\
82 \in[47,128]\end{array}$ & $\begin{array}{c}P \sim I \\
48 \in[22,53]\end{array}$ & $\begin{array}{c}\mathrm{P} \sim \mathrm{R} \\
44 \in[42,113]\end{array}$ & $\begin{array}{c}\mathrm{P} \sim \mathrm{R} \\
70 \in[42,113]\end{array}$ \\
\hline $\begin{array}{c}F \sim 1 \\
306 \in[297,396]\end{array}$ & $\begin{array}{c}F-I \\
364 \in[297,396]\end{array}$ & $\begin{array}{c}\mathbf{F}>\mathbf{I} \\
277 \notin[297,396]\end{array}$ & $\begin{array}{c}\mathrm{F}>\mathrm{I} \\
254 \notin[297,396]\end{array}$ & $\begin{array}{c}F>I \\
240 \notin[297,396]\end{array}$ & $\begin{array}{c}\mathrm{F} \sim \mathrm{I} \\
343 \in[297,396]\end{array}$ & $\begin{array}{c}F<1 \\
432 \notin[297,396]\end{array}$ & $\begin{array}{c}F>I \\
287 \notin[297,396]\end{array}$ & $\begin{array}{c}F \sim I \\
376 \in[297,396]\end{array}$ & $\begin{array}{c}F-I \\
323 \in[297,396]\end{array}$ \\
\hline $\begin{array}{c}\mathrm{P} \sim \mathrm{R} \\
53 \in[50,140]\end{array}$ & $\begin{array}{c}\mathrm{P}<\mathrm{R} \\
151 \notin[50,140]\end{array}$ & $\begin{array}{c}\mathrm{P}>\mathrm{I} \\
22 \notin[25,60]\end{array}$ & $\begin{array}{c}P \sim 1 \\
42 \in[25,60]\end{array}$ & $\begin{array}{c}\mathrm{P}>\mathrm{I} \\
23 \notin[25,60]\end{array}$ & $\begin{array}{c}\mathrm{P}<\mathrm{R} \\
155 \notin[50,140]\end{array}$ & $\begin{array}{c}\mathrm{P} \sim \mathrm{I} \\
54 \in[25,60]\end{array}$ & $\begin{array}{c}\mathrm{P} \sim \mathrm{I} \\
57 \in[25,60]\end{array}$ & $\begin{array}{c}P \sim R \\
87 \in[50,140]\end{array}$ & $\begin{array}{c}P \sim R \\
84 \in[50,140]\end{array}$ \\
\hline $\begin{array}{c}F \sim I \\
328 \in[304,410]\end{array}$ & $\begin{array}{c}F \sim I \\
343 \in[304,410]\end{array}$ & $\begin{array}{c}F \sim I \\
323 \in[304,410]\end{array}$ & $\begin{array}{c}\mathrm{F}>\mathrm{I} \\
237 \notin[304,410]\end{array}$ & $\begin{array}{c}F>1 \\
261 \notin[304,410]\end{array}$ & $\begin{array}{c}\mathrm{F} \sim \mathrm{I} \\
329 \in[304,410]\end{array}$ & $\begin{array}{c}F \sim I \\
371 \in[304,410]\end{array}$ & $\begin{array}{c}\mathbf{F} \sim \mathbf{I} \\
315 \in[304,410]\end{array}$ & $\begin{array}{c}F \sim I \\
382 \in[304,410]\end{array}$ & $\begin{array}{c}F-I \\
405 \in[304,410]\end{array}$ \\
\hline $\begin{array}{c}P \sim R \\
52 \in[52,143]\end{array}$ & $\begin{array}{c}\mathrm{P}<\mathrm{R} \\
166 \notin[52,143]\end{array}$ & $\begin{array}{c}P \sim R \\
59 \in[52,143]\end{array}$ & $\begin{array}{c}P \sim I \\
51 \in[26,64]\end{array}$ & $\begin{array}{c}P-I \\
27 \in[26,64]\end{array}$ & $\begin{array}{c}\mathrm{P}<\mathrm{R} \\
153 \approx[52,143]\end{array}$ & $\begin{array}{c}P \sim R \\
94 \in[52,143]\end{array}$ & $\begin{array}{c}P<R \\
147 \notin[52,143]\end{array}$ & $\begin{array}{c}\mathrm{P} \sim \mathrm{R} \\
66 \in[52,1.43]\end{array}$ & $\begin{array}{c}P \sim R \\
90 \in[52,143]\end{array}$ \\
\hline
\end{tabular}

Source: Author's estimates.

1 The last three rows of the table correspond to the subperiods 1990-92, 1993-95, and 1996-98, respectively. The cells show the values of the test statistic and the

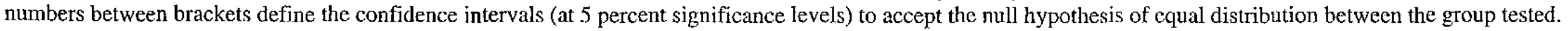

The notation is as follows: $\mathrm{F} \equiv$ private foreign bank; $\mathrm{I} \equiv$ private indigenous bank; $\mathrm{P} \equiv$ public bank; $\mathrm{R} \equiv$ all private banks, comprising $\mathrm{F}$ and $\mathrm{I}$.

$\underline{2}$ A bank size is defined as a bank's assets relative to the ECCB system's total assets.

$\underline{3}$ Also called "overhead." It comprises personnel costs and other non-interest expenses, excluding provisions.

4 The data on provisions (a component of noninterest expenses) for public banks may not be reliable.

$\underline{5}$ Net interest income is defined as intcrest income minus interes expense.

$\underline{6}$ Profit is defined as before-taxe profits.

2 The results would indicate that public banks have either a large proportion of subsidized loans, or a large proportion of problem loans.

8 Investors obtained the same rate of return for their deposits at either group of banks for 1990-92 and 1996-98.

2 Except for the subperiod 1990-92, there is consistency with the results show in the previous two columns.

$\underline{10}$ Neither F nor I is particularly affected by nonperforming loans. P seemed affected by problem loans during the first subperiod; but not in the subsequent periods.

11 The results would indicate that neither group of banks (F, I, and P) is systematically remunerating deposits by more or less than quoted. 


\section{Bank's total asset as a percent of ECCB's area total asset (bank size)}

The hypotheses examined were: whether private indigenous banks are statistically different in size than private foreign banks, and whether public banks were statistically different in size from the rest of the banks. To address the first question, public banks were excluded from the sample, and all private banks were ranked by size in descending order-that is, from the largest to smallest bank-for each of the three subperiods considered.

We accept the null hypothesis of no difference in size between private indigenous and private foreign banks for all three of the subperiods under review. Furthermore, the statistical significance of the test results is highest in the most recent subperiod, suggesting that these groups tended to have more similar distributions over time.

The distribution of public banks increasingly resembled that of the private banks, since the rankings of public banks has become more intermixed with the rest (private indigenous and private foreign banks) over time. For instance, during the subperiod 1990-92, public banks were relatively larger than the rest. However, for the subsequent periods, the size of public banks tended to be more dispersed in the whole distribution of banks by size.

\section{Operating expenses as a percent of total assets}

For the period 1996-98, the average operating expenses as a percentage of assets for the ECCB area banking sector was 4.3 percent. By comparison, Claessens, Demirguic-Kunt, and Huzinga (1998) report that banks' administrative expenses as a percent of assets were 2.6 percent in industrial countries and 6.1 percent in Latin America.

For the three subperiods, foreign and indigenous private banks belong to the same distribution, i.e., private foreign and private indigenous banks are equally efficient from the viewpoint of operating expenses as percent of total assets.

For the three subperiods, public banks and rest of the banks (private foreign and private indigenous) do not belong to the same distribution. Interestingly, for the three subperiods, public banks are in the lower part of the ranking; thus, according to this indicator, public banks appear to be more efficient than the rest.

\section{Net noninterest income as a percent of total assets}

For the first two subperiods, private foreign exhibited higher net non-interest income as percent of total assets than private indigenous banks; however, this advantage disappeared in last subperiod.

For the first two subperiods public banks had equally and higher net non-interest income as percent of total assets than private indigenous banks, respectively. However, during 1996-98, public banks were intermixed with the rest. 


\section{Net interest income as a percent of total assets}

For the three subperiods, private foreign and private indigenous banks do not belong to the same distribution. In particular, private foreign banks exhibited higher net interest income as a percentage of assets than did private indigenous banks.

For the three subperiods, public banks and private indigenous banks belong to the same distribution. Thus, for all subperiods, public banks had net interest income as a percent of assets similar to those of private indigenous banks.

\section{Before-tax profit as a percent of total assets (bank profitability)}

For the three subperiods, private foreign banks appear to be more profitable than private indigenous banks, thereby corroborating the results, cited earlier, that private foreign banks exhibit greater net interest income as a percentage of total assets and similar operating expenses as the private indigenous banks.

For the three subperiods, public banks and private indigenous banks belong to the same distribution, thus public banks are in general as profitable as private indigenous banks, but less profitable than private foreign banks.

\section{Implicit lending rate (interest income as a percent of total loans)}

For the three subperiods, private foreign banks obtained the same rate of return on loans (implicit lending rate) as private indigenous banks. We also obtained the same results (not reported) when the test was applied to the weighted average of quoted rates (explicit lending rates). These results imply that there is arbitrage in the loan rate charged by both groups.

For the three subperiods, public banks obtained lower rate of return on loans (implicit lending rates) than the rest of banks (private foreign and private indigenous). We also obtained the same results (not reported) when the test was applied to the weighted average of quoted rates (explicit lending rates). These results imply that public banks have a large proportion of subsidized loans.

\section{Implicit deposit rate (interest expense as a percent of total deposits)}

For the subperiods of 1990-92 and 1996-98, private foreign and private indigenous banks belong to the same distribution. For those periods, investors obtained the same rate of return for their deposits (implicit deposit rate) at either private foreign banks or private indigenous banks. However, for the subperiod of 1993-95, investors obtained a lower rate of return for their deposits at private foreign banks than at the private indigenous banks.

For the subperiods of 1990-92 and 1996-98, public banks and the rest (private foreign and private indigenous banks) belong to the same distribution, implying that investors obtained the same rate of return for their deposits at either public banks or the rest of banks. However, 
for the subperiod 1993-95, investors obtained the same rate of return for their deposits at either public banks or private indigenous banks.

\section{Implicit lending rate minus implicit deposit rate (spread)}

For the first two subperiods, private foreign banks had in general a larger spread than private indigenous banks. However, for the subsequent period, 1996-98, private foreign and private indigenous belong to the same distribution; thus, neither group had consistently a different spread.

For the first two subperiods, public banks had the same spread as private indigenous banks (but they had a lower spread than foreign banks). For the subsequent period, 1996-98, public banks had lower spreads than the rest of banks.

\section{Weighted average of explicit lending rates minus the implicit lending rate}

In the absence of information on nonperforming loans, the quality of banks' loan portfolio was proxied by the difference between the weighted average interest rate quoted on loans (based on data reported by the banks to the ECCB) and the implicit lending rate $\longrightarrow$ this difference is connoted by $\mathrm{D}_{\mathrm{L}}$. If all bank loans were performing, then the quoted loan rate would be expected to equal the implicit lending rate, and in the presence of nonperforming loans, the implicit loan rate would be expected to be lower than the quoted rate. Banks were ranked in descending order according to the value of $\mathrm{D}_{\mathrm{L}}$ (from positive to negative values). As suggested above:

$\mathrm{D}_{\mathrm{L}}>0 \Rightarrow$ the bank's return on loans was less than anticipated, due perhaps to nonperforming loans. ${ }^{12}$

$\mathrm{D}_{\mathrm{L}}=0 \Rightarrow$ the bank's return on loans was as anticipated, due maybe to the absence of nonperforming loans.

$\mathrm{D}_{\mathrm{L}}<0 \Rightarrow$ the bank's return on loans is higher than first anticipated, due perhaps to the absence of nonperforming loans combined with other returns on loans not captured in the quoted rate.

For the three subperiods, private foreign and private indigenous banks belong to the same distribution. This would indicate that neither group of banks (private foreign or private indigenous) are particularly affected by nonperforming loans.

During 1990-92, public banks were on the positive side of the distribution of $D_{L}$, thus indicating the presence of problem loans-note that the nonparametric test indicates the

${ }^{12}$ A positive value of $D_{L}$ could also indicate that loans are expanding quickly and interest payments are due with some lag. However, loans did not expand rapidly in the region. 
public banks were intermixed with the rest of banks, however, these results are marginal as the value of the test statistic is close to the lower bound of the confidence interval. Given the marginal results of the test, we conducted an alternative ad hoc test: Assuming possible measurement errors, we set the criteria that $D_{L}$ should be larger than 1.5 percentage points to be considered significatively larger than zero. Under this criteria, in 1990-92, some public banks might have experienced problem loans as 3 out of 6 public banks were in the region of $\mathrm{D}_{\mathrm{L}}>1.5$ percentage points.

For the subsequent subperiods of 1993-95 and 1996--98, the nonparametric tests reveal that public banks belongs to the same distribution as the rest of banks, thus indicating that neither group were particularly affected by problem loans. The same conclusion arises when using the criteria just mentioned: In 1993-95 and 1996-98, none of the public banks had $\mathrm{D}_{\mathrm{L}}$ larger than 1.5 percentage points.

\section{Weighted average of explicit deposit rates minus the implicit deposit rate}

The significance of this variable, denoted by $\mathrm{D}_{\mathrm{D}}$, is as follows:

$\mathrm{D}_{\mathrm{D}}>0 \Rightarrow$ that, on average, the bank is paying less than the announced rates, perhaps capitalizing on their perceived solvency and name recognition among depositors.

$\mathrm{D}_{\mathrm{D}}=0 \Rightarrow$ that, on average, the bank is paying the announced rates.

$\mathrm{D}_{\mathrm{D}}<0 \Rightarrow$ that, on average, the bank has to pay more than quoted to attract depositors, perhaps indicative of an implicit risk premium required by depositors because the bank is in problem.

For the three subperiods, private foreign and private indigenous banks belong to the same distribution. This would indicate that neither group of banks (private foreign or private indigenous) is systematically remunerating deposits by more or less than what is quoted. The same conclusions were obtained when examining public banks versus private banks.

\section{Conclusion and Agenda for Future RESEARCH}

The foregoing analysis examined the structure of bank ownership in the Eastern Caribbean, with a view to analyzing its evolution since the writing of the CAFAS study in 1987. In this regard, the study noted that although private foreign banks remained dominant throughout the nineties, their market share (in terms of either assets, loans, or deposits) declined marginally during the nineties (by about 1 to 3 percentage points). In addition, the market share of the public banks also declined (by about 1 to 4 percentage points), while that of the private indigenous banks increased considerably. 
The degree of monetization and financial deepening in the ECCB area increased in the 1990 s, thus continuing the trend that has been ongoing in the region since mid-1970 as reported by the CAFAS study. Regarding dollarization, we found evidence of minimal dollarization in the system-suggesting high credibility in the currency union and in the exchange rate regime-and that operating in foreign currency is not a peculiarity of foreign banks. With respect to lending, we did not find evidence of a lending boom in the 1990s, either for the system as a whole or for any of the subgroups (by country and by ownership).

Analysis of the Herfindahl asset concentration index revealed that, throughout the review period, actual market power was not concentrated in a small number of banks. Moreover, this finding was not only true for the whole sample of banks, but also for each of the ownership subgroups. We also group banks by countries regardless of ownership and found that in general banks were not concentrated either within a country or across countries. Also, no general dominance of foreign over indigenous banks based on size from an individual country perspective was observed.

Using Stigler's survivor test, we found that large-sized banks tended to reduce their scale throughout the period 1984-98. To further explore the issue of optimal scale, we plotted scatter diagrams, for three subperiods in the nineties, of bank size against before-tax profit as a percent of total assets and against operating expenses as a percent of total assets. Those diagrams suggest that larger size banks do not have any efficiency advantages.

The application of the Wilcoxon-Mann-Whitney nonparametric test to assess the statistical significance of differences in bank performance indicators across ownership groups of banks in the ECCB area, yielded the following main conclusions:

1. Throughout the review period, private foreign and private indigenous banks belonged to the same size distribution, although marginally in the first two subperiods. The significance of the test indicates that in the first two subperiods there were more foreign banks among the largest banks but they were more intermixed in the third subperiod. Public banks were of a larger size than private banks, particularly during the subperiod 1990-92, but this size advantage diminished with time.

2. Throughout the review period, private foreign and private indigenous banks exhibited similar efficiency distributions (with efficiency measured as operating expenses divided by average total assets), while public banks, interestingly, appeared to be more efficient than the rest of banks (indigenous and foreign). We do not have an explanation for this observation.

3. Throughout the review period, private foreign banks were more profitable than their private indigenous counterparts, and public banks experienced the same profitability as the group of private indigenous banks. This appears to be chiefly attributable to higher net interest income attained by the group of private foreign banks.

4. The study found, as Randall (1998) did, that interest rate spreads in the ECCB remained high in the 1990 s continuing the trend noted in the 1970 s and 1980 s by the 
CAFAS study. However, unlike in the 1970 s and 1980s, profits of the banking system were not considered exceptionally high when judged relative to international standards (the average return on assets during 1990-98 was 2.5 percentage points). Moreover, since all private banks (regardless of ownership) tended to belong to the same size distribution and exhibited similar cost efficiency, the high interest rate spreads could be attributable to high average costs caused by the limited size of the market and the geographic peculiarities of those countries.

5. The CAFAS study also concluded that indigenous banks tended to have both higher deposit rates and lower lending rates; and thus, a lower spread than private foreign banks. However, the nonparametric tests suggest that in the nineties all banks (regardless of ownership) tended to belong to the same distribution for (implicit and quoted) deposit rates. Moreover, both private indigenous and private foreign banks appeared to belong to the same distribution for (implicit and quoted) lending rates. Throughout the review period, public banks had lower (implicit and quoted) lending rates than the rest of banks (indigenous and foreign), suggesting that public banks had a larger proportion of subsidized loans than the rest.

6. In the absence of time series information on nonperforming loans, the quality of a bank's loan portfolio was proxied by $\mathrm{D}_{\mathrm{L}}$, which is the difference between the weighted average interest rate quoted on loans and the implicit lending rate. If all bank loans were performing, then $\mathrm{D}_{\mathrm{L}}$ would be expected to equal zero, and in the presence of nonperforming loans, $\mathrm{D}_{\mathrm{L}}$ would be expected to be larger than zero. The empirical analysis of $D_{\mathrm{L}}$ revealed that neither private foreign banks nor private indigenous banks is particularly affected by nonperforming loans; and that public banks had more problem loans than the rest of banks during 1990-92, but the problem appeared to have diminished over time.

Our study focused on a rather descriptive but comprehensive statistical analysis of various characteristics of the banking system in the ECCB area during the nineties. We used a data set provided by the ECCB. Although we believe that we have addressed important questions, there are several other issues to be addressed in future research. It is our hope that future papers along this line, using an expanded data set and econometric techniques when appropriate further the research that was initiated here. Some unanswered questions include the following:

- What are the principal factors influencing economies of scale in the ECCB area banking system? Possible factors might include: inadequate financial integration and low levels of human capital.

- Are there any additional characteristics which distinguish foreign banks from indigenous banks?

- Why do public banks exhibit lower operating costs as a percentage of GDP than the rest of the banking system? 
- Is there a role for public banks in the ECCB area?

- How could greater integration of the financial market in the ECCB area be achieved, and what impact might this have on lending rates and bank operating costs?

- What remains to be done regarding prudential regulations in the ECCB area banking system?

- Future work will explore comparisons of banking performance among other CARICOM countries. 


\section{References}

Canhoto, Ana, and Jean Dermine (2000), "A Non-Parametric Evaluation of Banking Efficiency in Portugal," New vs. Old Banks. Universidade Catolica Portuguesa, January.

Claessens, S., A. Demirguic-Kunt, and H. Huzinga (1998), "How Does Foreign Entry Affect the Domestic Banking Market?" Policy Research Working Paper No. 1918, The World Bank.

Barajas, Adolfo, Roberto Steiner, and Natalia Salazar, (2000), "The Impact of Liberalization and Foreign Investment in Colombia's Financial Sector," Journal of Development Economics, Vol. 63, pp. 157-196.

Barajas, Adolfo, Roberto Steiner, and Natalia Salazar, (1999), "Interest Spreads in Banking in Colombia," IMF Staff Papers, Vol. 46, pp. 196-224.

Birchwood, Anthony, (2000), "Banking Strategy and Performance: The Case of Banks in CARICOM," Working Paper, Central Bank of Barbados.

Comision Nacional Bancaria y de Valores de Mexico (Mexican National Banking Commission), Statistical Information, www.cnbv.gob.mx

Demirguic-Kunt, Asli, and H. Huzinga (1998), "Determinants of Commercial Bank Interest Margins and Profitability," Policy Research Working Paper No. 1900, The World Bank.

Demirguc-Kunt, Asli, Enrica Detragiache, and Poonam Gupta (2000), "Inside the Crisis: An Empirical Analysis of Banking Systems in Distress." The World Bank and IMF, June.

Dixon, Wilfrid J., and Frank J. Massey, Jr., "Introduction to Statistical Analysis," McGrawHill, Inc. Fourth Edition, 1983.

Dueñas, Daniel and V. Hugo Juan-Ramón, "The Mexican Banking System," Chapter II of the Mexico-1995 Recent Economic Development, IMF, SM/95/153.

ECCB, Bank Supervision Department, (1997), "Is the ECCB Area Overbanked?" Unpublished, April 1997.

ECCB, Research Department, (1987), "Financial Markets in the Eastern Caribbean Central Bank Area: A Policy for Commercial Rates of Interest." A Report by Crown Agents Financial Advisory Service (CAFAS), Unpublished, March 1987. 
Gavin, Michael, and Ricardo Hausmann (1996), "The Roots of Banking Crises: The Macroeconomic Context," in Banking Crises in Latin America, Edited by Ricardo Hausmann and Liliana Rojas-Suarez, Inter-American Development Bank, Washington, D.C., 1996.

IMF, "The Eastern Caribbean Currency Union-Recent Development and Policy Issues." Washington, D.C., March 12, 1999; (SM/99/69).

Larson, Harold J., "Introduction to Probability Theory and Statistical Inference," John Wiley and Sons. Third Edition, 1982.

Randall, Ruby (1998), "Interest Rate Spread in the Eastern Caribbean," IMF Working Paper, WP/98/59.

Rojas-Suarez, Liliana, and Steven R. Weisbrod, (1996) "Banking Crisis in Latin America: Experiences and Issues," in Banking Crises in Latin America, Edited by Ricardo Hausmann and Liliana Rojas-Suarez, Inter-American Development Bank, Washington, D.C., 1996.

Steiner, Roberto, Adolfo Barajas, and Natalia Salazar, (1998), "Interest Spreads in Banking: Costs, Market Power and Credit Risk in the Colombian Case 1991-96," IMF, Working Paper, January, 1998.

Stigler, George J., "The Economics of Scale," Journal of Law and Economics, Vol. 1, 1958.

------, "The Theory of Price," Macmillan Publishing Co., Inc. New York, 1966.

Stotsky, Janet, Esther Suss, and Stephen Takarick (2000), "Trade Liberalization in the Caribbean." Finance and Development, IMF, June. www.imf.org/fandd

Sundararajan, V., and Tomas J. Balino, eds. (1991), "Banking Crises: Cases and Issues." Washington, D.C., International Monetary Fund.

Van Beek, Fritz., Jose R. Rosales, Mayra Zermeño, Ruby Randall, and Jorge Shephard, "The Eastern Caribbean Currency Union Institutions Performance and Policy Issues." IMF Occasional Paper No. 195, July, 2000. 
Table 13. Caribbean Regions and Countries: Summary Indicators

(1994-98 averages, unless otherwise indicated)

\begin{tabular}{|c|c|c|c|c|c|c|c|c|c|}
\hline $\begin{array}{l}\text { Regions } \\
\text { and } \\
\text { Countries }\end{array}$ & $\begin{array}{c}\text { Nominal GDP } \\
\text { per capita } \\
1998 \\
\text { (dollars) 1/ }\end{array}$ & $\begin{array}{c}\text { Nominal } \\
\text { GDP } \\
1998 \\
\text { (million } \\
\text { dollars) }\end{array}$ & $\begin{array}{c}\text { Population } \\
1998 \\
\text { (millions) }\end{array}$ & $\begin{array}{l}\text { Real GDP } \\
\text { growth } \\
\text { rate } \\
\text { (percent) }\end{array}$ & $\begin{array}{l}\text { Consumer } \\
\text { price index } \\
\text { (percent } \\
\text { change) }\end{array}$ & $\begin{array}{l}\text { Current } \\
\text { account } \\
\text { balance } \\
\text { (percent } \\
\text { of GDP) }\end{array}$ & $\begin{array}{l}\text { Exports and } \\
\text { imports of goods } \\
\text { and services } \\
\text { (percent } \\
\text { of GDP) }\end{array}$ & $\begin{array}{l}\text { Consolidated } \\
\text { public sector } \\
\text { balance } \\
\text { (percent } \\
\text { of GDP) }\end{array}$ & $\begin{array}{c}\text { Central } \\
\text { government } \\
\text { expenditure } \\
\text { (percent } \\
\text { of GDP) } \\
\end{array}$ \\
\hline \multicolumn{10}{|l|}{ ECCB area } \\
\hline Antigua and Barbuda & 8,833 & 617 & 0.07 & 3.5 & 1.9 & -11.2 & 171.0 & 5.4 & 25.7 \\
\hline Dominica & 3,100 & 260 & 0.07 & 2.6 & 1.4 & -12.3 & 115.6 & 1.4 & 36.3 \\
\hline Grenada & 3,209 & 336 & 0.10 & 4.5 & 1.9 & -9.5 & 111.3 & 2.4 & 31.3 \\
\hline St. Kitts and Nevis & 6,935 & 291 & 0.04 & 5.2 & 4.1 & -22.0 & 147.4 & 3.8 & 34.5 \\
\hline St. Lucia & 4,013 & 610 & 0.15 & 2.7 & 2.8 & -8.9 & 118.2 & -1.4 & 27.4 \\
\hline $\begin{array}{l}\text { St. Vincent and } \\
\text { the Grenadines }\end{array}$ & 2,745 & 316 & 0.12 & 3.2 & 2.4 & -15.3 & 118.2 & 0.3 & 31.2 \\
\hline \multicolumn{10}{|l|}{ Rest of the Caribbean } \\
\hline The Bahamas & 14,450 & 4,190 & 0.29 & 2.4 & 1.4 & -10.3 & 102.2 & 1.4 & 20.4 \\
\hline Barbados & 8,212 & 2,389 & 0.27 & 4.0 & 2.2 & 3.5 & 121.8 & -0.6 & 31.7 \\
\hline Belize & 2,820 . & 682 & 0.23 & 2.4 & 2.3 & -3.3 & 105.7 & 4.3 & 27.7 \\
\hline Guyana & 932 & 726 & 0.77 & 5.8 & 8.6 & -14.7 & 211.3 & 1.8 & 39.2 \\
\hline Jamaica & 2,604 & 6,880 & 2.64 & -0.5 & 23.5 & -2.4 & 122.5 & 4.2 & 32.5 \\
\hline Suriname & 1,495 & 640 & 0.43 & 7.2 & 246.4 & 6.4 & 174.7 & 3.1 & 40.9 \\
\hline Trinidad and Tobago & 4,565 & 6,083 & 1.33 & 4.1 & 5.0 & -2.0 & 95.8 & -0.4 & 27.0 \\
\hline ECCB Area ${ }^{2}$ & 4,418 & 2,430 & 0.55 & 3.5 & 2.4 & -12.3 & 133.9 & 2.0 & 29.8 \\
\hline Caribbean Region $^{2}$ & 3,684 & 24,020 & 6.52 & 2.6 & 15.6 & -4.3 & 116.9 & 1.7 & 28.9 \\
\hline
\end{tabular}

Source: Table 1 in "Trade Liberalization in the Caribbean," Finance and Development, June 2000

1997 for Barbados, Belize, and Guyana.

${ }^{2}$ Except for the first three columns, averages are weighted by nominal GDP in U. S. dollars.

${ }^{3}$ Combined nominal GDP per capita. 
Table 14. Eastern Caribbean Area: Banks’ Panel Identified by Country, Code and Ownership ${ }^{13}$

\begin{tabular}{|c|c|c|}
\hline Country & Bank Code & Bank Ownership \\
\hline \multirow[t]{9}{*}{ Antigua and Barbuda } & A_F_1 & Private Foreign \\
\hline & A_F_2 & Private Foreign \\
\hline & A_F_3 & Private Foreign \\
\hline & A_F_4 & Private Foreign \\
\hline & A_I_1 & Private Indigenous \\
\hline & A_I_2 & Private Indigenous \\
\hline & $\mathrm{A} I 3$ & Private Indigenous \\
\hline & A_1_4 & Private Indigenous \\
\hline & A_I_5 & Private Indigenous \\
\hline \multirow[t]{5}{*}{ Dominica } & D_F_1 & Private Foreign \\
\hline & D_F_2 & Private Foreign \\
\hline & D_F_3 & Private Foreign \\
\hline & D_F_4 & Private Foreign \\
\hline & $\mathrm{D}_{2} \mathrm{P}_{2}$ & Public Indigenous \\
\hline \multirow[t]{7}{*}{ Grenada } & G_F_1 & Private Foreign \\
\hline & GP_2_1 & Public Indigenous $1990-92$ \\
\hline & G_F_2_2 & Private Foreign 1992- \\
\hline & G_F_3 & Private Foreign \\
\hline & G_P_1_1 & Public Indigenous $1990-96$ \\
\hline & G_l_1_2 & Private Indigenous \\
\hline & G_I_2 & Private Indigenous \\
\hline \multirow[t]{6}{*}{ St. Kitts and Nevis } & K_F_1 & Private Foreign \\
\hline & K_F_2 & Private Foreign \\
\hline & $\mathrm{K}_{-} \mathrm{F}_{2} 3$ & Private Foreign \\
\hline & $\mathrm{KI} 1$ & Private Indigenous \\
\hline & $\mathrm{K} \_\mathrm{I} 2$ & Private Indigenous \\
\hline & K_P_3 & Public Indigenous \\
\hline \multirow[t]{7}{*}{ St. Lucia } & S_F_l & Private Foreign \\
\hline & S_F_2 & Private Foreign \\
\hline & S_F_3 & Private Foreign \\
\hline & S_F_4 & Private Foreign \\
\hline & S_I_1 & Private Indigenous \\
\hline & S_P_2 & Public Indigenous \\
\hline & S_l_3 & Private Indigenous \\
\hline \multirow[t]{5}{*}{ St. Vincent and the Grenadines } & V_F_1 & Private Foreign \\
\hline & V_F_2 & Private Foreign \\
\hline & V_F_3 & Private Foreign \\
\hline & VII_1 & Private Indigenous \\
\hline & V_P_2 & Public Indigenous \\
\hline
\end{tabular}

${ }^{13}$ The ordering does not correspond to the ordering of the banks shown in Table 1 in the text, in order to preserve bank confidentiality. 


\section{ECCB: Institutional Requirements}

\section{Credit policy to governments}

The ECCB is required to maintain its external reserves at a level that is at least 60 percent of its monetary liabilities. In practice, however, the level of foreign exchange cover typically has exceeded this requirement, and at end-December 1998 it was 97.7 percent. The Bank is authorized to make temporary advances to member governments amounting to no more than 5 percent of each government's average annual recurrent revenue based on the three preceding financial years.

Holdings of treasury bills of any one government cannot exceed 10 percent of the estimated recurrent revenue of that government, as determined by the central bank for the current year. Holdings of government securities, other than treasury bills, may not exceed 15 percent of currency in circulation and other demand liabilities. Holdings of bonds issued by development finance corporations may not exceed 2.5 percent of the average annual government revenue over the preceding three years. The ECCB's provisions also call for a general reserve fund equivalent to 10 percent of demand liabilities, which must be replenished (according to prescribed rules), if necessary, before the distribution of ECCB profits to member countries.

\section{Commercial banks legal requirements}

Legal requirements faced by all licensed financial institutions include (a) a minimum paid-up capital requirement; (b) the maintenance of a statutory reserve fund; (c) restrictions on lending to related parties; (d) a restriction on large credit exposure; (e) restrictions governing the nature of bank investments; and (f) satisfaction of a reserve requirement.

- The minimum paid-up capital requirement for newly established locally incorporated banks is EC\$5 million. The applicable minimum paid-up capital requirement for nonbank financial institutions is determined by the relevant ministry of finance in consultation with the ECCB, but it should not be less than EC\$1 million. Foreign branch banks (namely, existing branches of foreign banks) are subject to an assigned minimum capital requirement of 5 percent of the branch's deposit liabilities, which is applied annually. This requirement is satisfied by the provision of a "letter of comfort" from the parent institution certifying that the assigned capital is being held in the books of the head office on behalf of each branch bank.

- Financial institutions are required to maintain a Statutory Reserve Fund equivalent to 100 percent of paid-up capital, and to transfer a minimum of 20 percent of annual profits to the Statutory Reserve Fund account until the fund is equal to the paid-up capital.

- Financial institutions are prohibited from providing unsecured credit to directors, external auditors/examiners and persons holding 10 percent or more of shares in the institution, except if a waiver is granted by the minister of finance after consultation 
with the ECCB. Moreover, credit facilities granted to such individuals cannot be provided at rates that are more favorable than those offered to other customers. Financial institutions are also prohibited from lending against their own shares.

- The stock of unsecured loans to any individual or group of related individuals must not exceed 15 percent of a banks unimpaired capital and reserves, but this restriction can be waived if loans are secured by acceptable collateral valued at 20 percent or more of the loan amount, and/or upon a decision by a country's minister of finance after consultation with the central bank.

- The Banking Act contains provisions, which limit the nature of bank commercial activity, including constraints on the acquisition of real estate, except for purposes of business expansion, and ownership interests in business ventures.

- Licensed commercial banks must comply with the 6 percent reserve requirement, on both Eastern Caribbean dollar and foreign currency deposits.

\section{Commercial banks prudential guidelines}

The ECCB first introduced prudential guidelines conforming to international best practices (as defined in the Basle Committee's banking supervision guidelines) in November 1994. These guidelines are, in many cases, more stringent than the requirements of the Universal Banking Act (UBA). The prudential guidelines have been adapted over time ${ }^{14}$ and at present they govern: (a) large credit exposures; (b) provisioning requirements for nonperforming loans; (c) an aggregate limit of 10 percent on the ratio of nonperforming assets to total assets (this limit has been in effect since 1987); (d) the suspension of interest on nonperforming assets; and (e) compliance with capital adequacy standards adapted by the CARICOM Bank Supervisors from the Basle Committee guidelines.

- $\quad$ Prudential guidelines on large credit exposures, issued in 1994, are consistent with the Basle Committees 1991 recommendations and require financial institutions to limit their exposure to any single individual or group of related persons to 25 percent of paid-up capital and reserves irrespective of the security provided. ${ }^{15}{ }^{16}$ Institutions

${ }^{14}$ In particular, in July 1995 the ECCB introduced additional prudential guidelines (including stricter provisioning standards) and expanded the reporting requirements of banks.

${ }^{15}$ Thus, this guideline is more stringent than the corresponding stipulation in the UBA; since, unlike the UBA, the guidelines do not allow for exceptions from the stipulated 25 percent. Since the provisions of the UBA have legal precedence over the prudential guidelines, there is a recognized need to harmonize the two documents.

${ }^{16}$ In this respect, a "group of related persons" is defined as "two or more persons, ... holding exposures from the same credit institution and of its subsidiaries, whether on a joint or separate basis, but who are mutually associated in that: (i) one of them holds directly or 
found to be in violation of this requirement are required to take immediate action to either reduce the exposure or increase the level of "Tier I capital" (see below).

- Under the "harmonized approach" to loan provisioning introduced in 1995, at least 70 percent of each financial institutions credit portfolio is subject to an annual review, at which time the quality of each bank loan is assessed and a grade is assigned that has associated with it a minimum provision level. This assessment is based on such criteria as the currentness and timeliness of debt-service payments; the presence and quality of collateral and/or other securitization; the degree of sensitivity to economic conditions; and the quality of the supporting loan documentation. Loans are then assigned the following labels, with the corresponding provisions: "pass," requiring no provision; "special mention," requiring no provision; "substandard" but fully secured by cash or government securities, which requires no provision; "substandard" with no securitization, requiring a 10 percent provision; "doubtful", requiring a 50 percent provision; and "loss," requiring a 100 percent provision. In addition, a maximum tolerable limit of 10 percent on the ratio of nonperforming or "unsatisfactory" assets to total assets was established; loans are classified as nonperforming when they have been in arrears for 90 days or more.

- Under guidelines governing the suspension of interest on nonperforming assets, banks are required to stop accruing interest on accounts that are 90 days or more in arrears, unless there is adequate security and full collection is expected within three months. Moreover, except in the case of loans to government or loans with a government-guarantee, banks are prohibited from accruing interest on overdrafts when the approved limit has been reached or when credits to the account are insufficient to cover interest accruals for at least a three-month period. In the case of government and government-guaranteed loans, accrual of interest is permitted up to the limit of the guarantee or up to the value of the collateral. A loan's accrual status is restored when all the arrears of principal and interest have been paid, and in the case of overdrafts accrual status is restored when the account is operating within the approved limit and all interest arrears have been cleared. Accrued, uAdPAENtedX III interest should be reflected in an "interest in suspense" account on the balance sheet.

- There are also guidelines governing the conditions under which loans and advances can be renegotiated owing to weaknesses in the borrower's financial position and/or the emergence of payment arrears. These guidelines include considerations pertaining

indirectly power of control over the other ... or; (ii) their cumulated exposures represent to the credit institution a single risk in so much as they are interconnected with the likelihood that if one of them experiences financial problems the other or all of them are likely to encounter repayment difficulties...." Relevant "interconnections" among persons include: "common ownership, common directors, cross guarantees, and direct commercial interdependency, which cannot be substituted in the short term." 
to the borrower's ability to service the loan under the new conditions and the adequacy of supporting securitization.

- Locally incorporated commercial banks are required to maintain the ratio of Tier I (or "core") capital to risk-weighted assets at a minimum of 8 percent. ${ }^{17}$ This capital adequacy ratio was adapted by the CARICOM Bank Supervisors from the Basle Committee guidelines, with the aim to be somewhat more stringent than that of the Basle Committee. The latter had been designed with larger and better-diversified banks in mind, and requires a ratio of total qualifying capital (Tier I and Tier II ${ }^{18}$ capital less investment in financial subsidiaries not included in the group consolidation) to risk-weighted assets of 8 percent.

- The ECCB guidelines also specify a liquidity requirement, namely that the ratio of Tier I capital to deposits not be less than 1:20.

${ }^{17}$ Tier I capital is comprised of paid-up ordinary share capital and surplus, paid-up perpetual noncumulative preference shares and share surplus; statutory reserves; capital reserves (excluding asset revaluations); general reserves (excluding reserves losses on assets); audited retained earnings (accumulated losses) less current year losses; bonus shares from capitalization of unrealized asset revaluation reserves; goodwill and other intangibles. Risk weights for balance sheet items are as follows: (a) zero percent risk for foreign and domestic currency cash and government securities; (b) 20 percent for claims on domestic and foreign financial institutions; (c) 50 percent for fully secured real estate residential mortgages; and (d) 100 percent for other claims on the private sector and for real estate and equity investments. Risk weights for off-balance sheet items are as follows: (a) a zero percent risk is attached to claims (with or without government guarantees) on domestic and foreign government entities; (b) a 20 per-cent risk is assigned to claims on domestic and approved foreign financial institutions, public sector entities and multilateral development banks; and (c) a 100 percent risk is assigned to claims on the private sector and other institutions.

${ }^{18}$ Tier II capital consists of fixed asset revaluation reserves (limited to 20 percent of Tier I capital); general provisions/reserves for losses on assets (limited to 1.25 percent of total riskweighted assets); paid-up perpetual cumulative preference shares and share surplus; bonus shares from capitalization of unrealized asset revaluation reserves; unaudited undivided profits; asset revaluation reserves; mandatory convertible debt instruments; other hybrid capital instruments; and subordinated term debt and limited life preference shares (limited to 50 percent of Tier I capital). 